\section{Ewa Pogonowska}

Uniwersytet

Marii Curie-Skłodowskiej

\title{
Krajobrazy post mortem. O Sołowkach, Kołymie (i nie tylko) we współczesnej polskiej prozie podróżniczej ${ }^{1}$
}

Jest takie opowiadanie Anatola France'a - Procurator Judei. I w nim Poncjusz Piłat nie może po siedemnastu latach przypomnieć sobie Chrystusa.

(Warłam Szałamow, Procurator Judei)

Prawda to jest to, co się pamięta.

(Zachar Prilepin, Klasztor)

Zostawić zmarłych w spokoju, żeby poleżeli ugorem (tak chłopi dają odpocząć polu, nie obsiewając go przez rok albo dłużej), z jakiegoś powodu wydaje się niemożliwe.

(Maria Stiepanowa, Pamięci pamięci)

\section{Abstract \\ Post-Mortem Landscapes: Regarding the Solovetsky Islands and Kolyma River (and Others) in Contemporary Polish Travel Prose}

The aim of this article is to demonstrate how contemporary Polish reporters describe the areas of former labor camps located in the Russian Federation, especially near the Kolyma River and on the Solovetsky Islands. The interest of Polish visitors is aroused

${ }^{1}$ Rozważania te stanowią kontynuację problematyki, którą podjęłam w artykule Rosja - między pamięcia a zapomnieniem (w świetle polskich dyskursów), „Slavia Orientalis” 2020, nr 1, s. 15-31. 
by the "landscapes of death" associated with the Gulag in their geographical, natural, cultural, and mental aspects. The essence of the traveler's interest lies in the Russian attitude towards the victims and perpetrators of Soviet terror as well as the daily life of the inhabitants of these sites. The source materials include, among others, the works of Ryszard Kapuściński, Mariusz Wilk, Jacek Hugo-Bader, and Michał Milczarek.

Słowa kluczowe: Gułag, terror stalinowski, krajobraz kulturowy, ofiary i sprawcy, groby masowe, pamięć o zmarłych, rozliczenie z przeszłością

Keywords: Gulag, Stalinist terror, cultural landscape, victims and perpetrators, mass graves, remembrance of the dead, reckoning with the past

„Przestrzenie śmierci były od wieków odwiedzane w ramach podróży pielgrzymkowych zarówno w charakterze religijnym, jak i historycznym mającym na celu upamiętnienie i kult zmarłych”". Współcześnie stanowić one mogą, poza żywym wciąż jeszcze kultem grobów i relikwii świętych, osobliwą turystyczną atrakcję podróżniczą. Wojaże do „miejsc związanych ze strasznymi rzeczami”’3, takimi jak miejsca kaźni, męki czy przestrzenie cmentarne wpisują się w nurt tak zwanej mrocznej turystyki (w literaturze angielskiej określanej jako dark tourism $)^{4} \mathrm{czy}-\mathrm{w}$ innej wersji - tanatoturystyki ${ }^{5}$. Motyw różnego typu peregrynacji do miejsc nazistowskich mordów w literaturze polskiej obecny jest od lat powojennych ${ }^{6}$. W wypadku podróży Polaków do Rosji mówić można o szczególnym znaczeniu, by nie powiedzieć popularności turystyki martyrologicznej, związanej z odwiedzaniem miejsc zbrodni systemu komunistycznego ${ }^{7}$. Z rosyjskimi przestrzeniami śmierci konfrontują się również profesjonalni podróżnicy, dzieląc się zapisem swych doświadczeń i wrażeń z czytelnikami, których interesują nie tylko skrywane do niedawna ślady stalinowskich represji, ale także to, jak wygląda codzienność w miejscach traumatycznych, jako że przestrzenie śmierci są

2 S. Tanaś, Tanatoturystyka. Od przestrzeni śmierci do przestrzeni turystycznej, Łódź 2013, s. 8.

${ }^{3}$ M. Kula, Ostatecznie trzeba umrzeć, Warszawa 2012, s. 58. Kula konstatował, że zainteresowania takie mogą się wydawać paradoksalne we współczesnej kulturze, używającej życia i odsuwającej myśl o śmierci.

${ }^{4}$ S. Tanaś, op.cit., s. 10.

5 Tanatoturystyka oznacza „podróże turystyczne, w ramach których odwiedzane są przestrzenie śmierci”. Ibidem, s. 9.

${ }^{6}$ Por. artykuł Arkadiusza Morawca: Tadeusza Różewicza wycieczka do muzeum (i biblioteki), „Czytanie Literatury. Łódzkie studia literaturoznawcze” 2013, nr 2, s. 15-36. Warto również wspomnieć o reporterskiej książce Marcina Kąckiego Oświęcim. Czarna zima, Kraków 2020, która ukazała się w Wydawnictwie Znak.

7 Zob. A. Horolets, Konformizm, bunt, nostalgia. Turystyka niszowa z Polski do krajów bytego ZSRR, Kraków 2013, s. 24. 
jednocześnie przestrzeniami życia. W szczególności zaciekawienie przybyszy budzą krajobrazy śmierci związane z Gułagiem ${ }^{8}$, gdyż łagry to - jak piszą autorzy Krasnojarska zero:

[...] przyschnięty, acz wciąż wyczuwalny wrzód na ciele rosyjskiego społeczeństwa, skupiający jak w soczewce wszystkie jego udręki. Wszechobecny w literaturze i wszelkiej poważnej refleksji nad tym krajem, a jednak jakby wyciszony, przemilczany, zbyt wstydliwy i bolesny, by go pamiętać i o nim mówić (JiM 49)9.

Zacytowane powyżej słowa posiłkujące się metaforami dobrze oddają nie tylko to, jak polscy podróżnicy postrzegają i opisują tutejsze „życie po życiu”, z mrocznym widmem przeszłości w tle, ale także, jak starają się zrozumieć na ogół bez większego powodzenia - stosunek współczesnych Rosjan, starych i młodych, do ofiar (i sprawców) sowieckiego totalitaryzm, ergo meandry ich (nie)pamięci.

\section{1. „Zły pejzaż”}

Współcześni polscy pisarze i reporterzy docierają do największych ośrodków Gułagu: Sołowek, Kołymy, Workuty. Wśród obszarów podróżniczego rekonesansu znalazły się również - leżące w obwodzie archangielskim - Jercewo, gdzie więziony był Gustaw Herling-Grudziński, a także Kotłas - tam prawdopodobnie w zbiorowej mogile spoczywa Eugeniusz Bodo ${ }^{10}$, oraz miejscowość Chołmogory (miejsce kaźni m.in. „białych” Rosjan) stanowiąca zaczątek tragicznej łagrowej historii. Miejsca te są już to głównym celem wędrówki po Rosji (Jacek Hugo-Bader), już to jednym z jej etapów (Ryszard Kapuściński, Michał Milczarek) lub wymiarów (Jacek Matecki), wreszcie zgoła życiową przystanią (Mariusz Wilk).

${ }^{8}$ Gułag - skrót od Gławnoje Uprawlenije Łagieriej, tzn. Główny Zarząd Obozów.

${ }_{9}$ Oznaczenia wykorzystanych tekstów źródłowych: W. Grzelak, Gra z Rosją do jednej bramki, rysunki S. Jołkin, Warszawa 2013: (Grz); J. Hugo-Bader, Dzienniki kołymskie, Wołowiec 2011: (HB); B. Jastrzębski, J. Morawiecki, Krasnojarsk zero, Warszawa 2012: (JiM); R. Kapuściński, Imperium, Warszawa 1993: (Kp); J. Matecki, Co wy, ..., wiecie o Rosji, Warszawa 2015: (Mt); M. Milczarek, Donikąd. Podróże na skraj Rosji, Wołowiec 2019: (Ml); P. Mitzner, Memoriat. Droga do Rosji, Kraków-Warszawa 2015: (Mtz); M. Wilk, Wilczy notes, Gdańsk 1998: (W1.1); M. Wilk, Wołoka, Kraków 2005: (W1.2). Po akronimie zamieszczony jest numer strony.

10 Miejscem pochówku aktora jest prawdopodobnie teren dawnych łagrów - cmentarz Makaricha. Tu znajduje się symboliczna mogiła artysty. 
Karl Schlögel uważa, że krajobraz „ma dobitniejszą i gęstszą wymowę niż kraj"11. Chodzi przecież nie tylko o terytorium polityczne, o geograficzny i przyrodniczy pejzaż czy klimat, ale także o nastrój i fluid miejsca. Według niego ,[1]udzie definiują się przez krajobrazy, z których się wywodzą w nie mniejszym stopniu niż poprzez kraj, którego są obywatelami"12. Istotne są uobecniające się w otoczeniu ślady przeszłości, wśród których miejscowi bardziej czy mniej świadomie funkcjonują, zmagając się ze swoją codziennością. Aktywność polskich podróżników przemierzających szlak dawnych łagrów polega $\mathrm{w}$ dużej mierze na próbach deszyfrowania stanowiącego szczególny system znaków tutejszego krajobrazu kulturowego. Jak słusznie bowiem twierdzi niemiecki historyk: „Każda epoka pozostawiła po sobie swój hieroglif”, każde pokolenie - „pakiet ważnych dla niego symboli”" ${ }^{\text {. }}$. Pisała na ten temat trafnie i obrazowo Małgorzata Czermińska:

W miejscu to czas jest podróżnikiem, który coś gubi, a coś ocala. [...] Choć miejsce pozostaje $w$ tych samych parametrach przestrzennych niewzruszone, to on jednak sprawia, że w nieruchomym terytorium zachodzi ruch, toczą się zmiany. [...] Przestrzeń fizyczna trwa, ale zmieniają się przypisywane jej znaczenia kulturowe, zmieniają się konkretne miejsca, ich charakter, symbolika, ludzie, którzy w nich żyją i je wypełniają $[\ldots]$.

[Z]miany zapisują się w miejscu, zostawiają ślady. Nowe warstwy, nakładając się na poprzednie i zakrywając je, zwykle nie czynią tego ze stuprocentową dokładnością, więc zamiast wymienić jedną powierzchnię na drugą, tworzą palimpsest, albo czasem zostawiają wyrwę, w której pustka nie jest zupełnie bez echa, bo krzyczy o nieobecności ${ }^{14}$.

Krajobrazy „po łagrach” intrygują i powodują niepokój, podobnie zresztą jak niektóre miejsca nazistowskich zbrodni, które mają - powtórzę za Pawłem Próchniakiem - „niepewną ontologię”, gdyż są „zarazem przeklęte i święte, przerażające i zwyczajne" ${ }^{15}$. Chodzi w tym wypadku tylko o tereny, które nie zostały namaszczone ludzką pamięcią, przestrzenie, gdzie nie realizuje się praktyk memorialnych. Wiele takich „,niemych” obszarów znajduje się na północnych terytoriach byłego ZSRR. Budzą konsternację, bo toczy się tam prze-

${ }^{11}$ K. Schlögel, W przestrzeni czas czytamy. O historii cywilizacji i geopolityce, przeł. I. Drozdowska, Ł. Musiał, posłowie H. Orłowski, Poznań 2009, s. 280.

${ }_{12}$ Ibidem.

13 Ibidem, s. 281.

${ }^{14}$ M. Czermińska, Tożsamość kształtowana w pamięci miejsca [w:] Kulturowa historia literatury, red. A. Łebkowska, W. Bolecki, Warszawa 2015, s. 147, 148.

15 P. Próchniak, Miejsca nieistnienia (wypisy) [w:] Pamięć i afekty, red. Z. Budrewicz, R. Sendyka, R. Nycz, Warszawa 2014, s. 493. 
cież normalne życie. Na tego rodzaju „miejscach po” na co dzień żywi koegzystują z umarłymi; lecz trudna to koegzystencja, skoro śmierć była gwałtowna, a uroczystości żałobne się nie odbyły.

Nawiasem mówiąc, opisywanie Gułagu z uwzględnieniem analogii z nazistowskimi obozami śmierci to dość powszechny chwyt retoryczny występujący w polskich narracjach o zbrodniach stalinizmu. Warto przypomnieć, że podobne zestawienia i porównania stanowią istotne narzędzie metodologiczne, a zarazem naukowe wyzwanie dla badaczy totalitaryzmów. Ryszard Kapuściński podkreślał, że do Magadanu wybrał się, aby „zobaczyć to najstraszniejsze, obok Oświęcimia, miejsce na świecie” (Kp 201), Jacek Hugo-Bader zaś nie zakwestionował narosłych wokół Kołymy określeń typu „białe krematorium” czy „mroźny koncłagier bez pieców” (HB 14). Inne natomiast stanowisko w tej kwestii zajął Mariusz Wilk. Autor Woloki wyraźnie zaznaczył, że nie zgadza się na próby utożsamiania sowieckich łagrów i niemieckich kacetów. Zastrzegł co prawda, że jego sprzeciw nie wynika bynajmniej z chęci usprawiedliwienia bolszewików, ale jednocześnie - trzeba zauważyć - kosztem efektowności zestawienia znacznie uprościł skomplikowane zagadnienie ${ }^{16}$.

Herling [-Grudziński - E.P.] mówi, że jedyna różnica między Oświęcimiem i Kołymą polegała na sposobach zabijania więźniów. Tymczasem ja zauważam, iż różnica - zasadnicza! - tkwiła w celu. Celem kacetów była eksterminacja więźniów, cele łagrów bywały różne: budowa kanału lub linii kolejowej, dobycie złota, ołowiu, uranu. Ba, same łagry były różne i wrzucanie ich do jednego wora nie ma sensu [...]. Zrównanie nazistowskich kacetów z sowieckimi łagrami zaciemnia rosyjski rodowód tych ostatnich, zamieniając go uniwersalnym (i w jakimś sensie oderwanym) pojęciem „totalitaryzmu” (W1.2 54-55).

Naznaczone śmiercią krajobrazy przedstawione przez Wilka różnią się w znacznym stopniu od „miejsc nie-pamięci” ${ }^{17}$ naszkicowanych przez Kapuścińskiego, Hugo-Badera czy - ostatnio - Michała Milczarka. Wpływa na to zarówno specyfika geograficznej scenerii, ze wszystkimi jej atrybutami, jak i owo - dostrzeżone również przez badaczy problematyki łagrowej - złudne podobieństwo zewnętrznych znaków Gułagu ${ }^{18}$. Ponadto - rzecz

${ }^{16} \mathrm{O}$ zasadniczych różnicach między obozami sowieckimi a nazistowskimi pisała m.in. Anne Applebaum. Zob. eadem, Gułag, przeł. J. Urbański, Warszawa 2005, s. 29-31.

${ }^{17}$ Wydaje się, że można tu zastosować pojęcie, które Roma Sendyka definiuje jako „lokalizacje rozmaitych aktów ludobójstw, których świadkiem był ubiegły wiek [...]. Wspólną cechą byłaby przeszła lub trwająca nadal obecność szczątków ludzkich, niezneutralizowana rytuałami pochówku". Eadem, Miejsca, które straszą (afekty i nie-miejsca pamięci) [w:] Pamięć i afekty, s. 285-286, przyp. 3.

18 Pisała na ten temat Zuzanna Bogumił. Zob. eadem, Pamięć GUŁagu, Kraków 2012, s. 316. 
oczywista - u poszczególnych reporterów mamy do czynienia z odrębnością podróżniczych doświadczeń tudzież punktów widzenia, warstwy językowo-stylistycznej i kompozycyjno-tematycznej. O indywidualnościach sylwetek autorów nie muszę przypominać.

Autor Imperium w czasie swych peregrynacji po martyrologicznej przestrzeni rosyjskiej łączy doświadczenie przestrzenne $\mathrm{z}$ wiedzą historyczną oraz lekturą wspomnień, w rezultacie - tyleż czyni żmudny rekonesans, ile dąży do syntezy, do zdefiniowania zbudowanej i nadzorowanej przez NKWD „struktury okrucieństwa” (Kp 163) oraz eksplikacji „logiki łagru” (Kp 218). Krajobraz Kołymy - pod względem natury i klimatu - jest z perspektywy Kapuścińskiego monochromatyczny i przygnębiający, przylega do rytmu życia tubylców, nie ma tam miejsca na nadzieję. Zbrodnia komunistyczna wtopiła się idealnie w fatalistyczny pejzaż Rosji, wywołujący cały szereg afektów negatywnych:

Świat ponury, monotonny, martwy. Bez drzew, bez ptaków. Nie widać żadnego ruchu, nie słychać żadnych odgłosów. [...] To otoczenie prowokuje do skrajnych zachowań, można tu wpaść w szał, w obłęd albo w najbardziej przygniatającą depresję; najtrudniej ocalić normalność i wiarę, że natura może być życzliwa, że nie chce się nas pozbyć. W takim miejscu jak Kołyma przyroda brata się z oprawcą, pomaga mu w niszczeniu bezbronnej i niewinnej ofiary, wysługuje się zbrodniarzom, płaszczy się przed nimi, podsuwając im coraz to nowe narzędzia tortur - trzaskający mróz, lodowate wichry, piętrowe śniegi, ogromne, niedające się przejść zimne pustynie (Kp 211).

Pomimo upływu czasu (podróż odbyła się na przełomie lat 80. i 90. ubiegłego wieku) poraża nędza łagrowego świata, rozrzucone „wizytówki” czy „zguby” Gułagu wprowadzają złowrogi chaos, poczucie niepewności i atmosferę niepokoju:

Puste łagry pozostały w starych dzielnicach, przy zaśnieżonych ulicach bez chodników i latarń. Część z nich przemieniono w jakieś składy i magazyny. Reszta niszczeje i rozsypuje się. Stoją jeszcze, widoczne to tu, to tam, wieżyczki wartownicze, krzywe, pochylone, butwiejące. W śniegu i błocie leżą rozbite bramy, płoty i słupy, bez drutu już - drut rozkradli. Większość baraków została rozebrana na drewno, na opał, kilka stoi jeszcze, ale są puste, bez drzwi i okien (Kp 214).

Dowody zbrodni w dużym stopniu zakryła natura - bagna, lasy, upływ czasu i skutki aktywności mieszkańców, wreszcie infrastruktura - nowe dzielnice, fabryki i stadiony sportowe. „Za kilka lat świat łagrów zatrze za sobą ostatnie ślady" (Kp 215) - konkluduje Kapuściński, obserwujący początki rozpadu sowieckiego imperium. 
Jednak, jak się okazuje, po latach cienie „mrocznego czasu” ${ }^{19}$, lekceważone na ogół przez tubylców, nie zniknęły; dowodzi tego w swej narracji Hugo-Bader. Autor na wstępie Dzienników kołymskich (2011) deklaruje, raczej z przekorą, że w jego opowieściach nie będzie „prawie nic”: „o Gułagu, obozach, więźniach, głodzie, śmierci, torturach" (HB 20, 18). Pragnie skupić się przede wszystkim na chwili obecnej, przypatrzyć się temu, jak żyje się w przestrzeni, która jest jednocześnie miejscem do życia i cmentarzem, chce sprawdzić, czy „[m]ożna się tu kochać, śmiać, krzyczeć z radości? Jak tu się płacze, płodzi i wychowuje dzieci, zarabia, pije wódkę, umiera?" (HB 22). Jednak Kołyma - „, biegun okrucieństwa”, ,ruska Golgota”, ,,arktyczne piekło" (HB 13-14) - nie pozwala, żeby potraktowano ją wyimkowo. Charakterystyczne, iż już na początku Hugo-Bader zaznacza: „Mówi się, że połowa obecnych mieszkańców Kołymy to potomkowie zeków, byłych więźniów łagrów. Drugie albo trzecie pokolenie" (HB 14). Dziennikarz, który chciałby skupić się na „nowym”, jednocześnie nie rezygnuje z prób dotarcia do bezpowrotnie odchodzących „ludzi wyjątkowych”. Wyjątkowych - bo „widzieli dno życia”, „w łagrze przeszli granicę, poza którą rozpada się wszelka dusza” (HB 20). Krajobraz „lutego bieguna” Archipelagu Gułag w ujęciu autora Dzienników kołymskich jest porażająco monotonny. Klucz do rozpoznania go stanowić może przywołana przez Czermińską metafora palimpsestu. Palimpsestowość sprowadza się w tym wypadku do dwóch warstw, z których dolna wyziera spod wierzchniej i nie daje się zignorować, pominąć. Uniemożliwia tym samym podróżnikowi odbycie takiej wyprawy, która nie uwzględniłaby motywu przewodniego tej jakże szczególnej przestrzeni. Przypomnijmy, że Hugo-Bader porusza się wzdłuż szlaku zbudowanego rękoma łagierników, nierzadko kosztem ich życia. „Policzyłem, że gdyby wszystkie ofiary kołymskich łagrów epoki Stalina położyć jedna za drugą, toby się na niej [Trasie Kołymskiej - E.P.] nie zmieściły"20 (HB 18) - konstatuje. Autor Dzienników, który przybył niejako na „miejsce zbrodni”, siłą rzeczy, gdy pisze o życiu, musi zahaczyć o śmierć. Ponieważ życie i śmierć współistnieją tu bardziej niż gdziekolwiek indziej. Nie przypadkiem dziennikarz zaznacza, że podróżuje

${ }^{19}$ K.K. Baczyński, Ten czas [w:] idem, Utwory wybrane, wybór i posłowie K. Wyka, Kraków-Wrocław 1986, s. 35.

${ }^{20}$ Reporter przeprowadza matematyczny rachunek, dzieląc liczbę kilometrów, a właściwie metrów stanowiących Trakt Kołymski przez liczbę równą przeciętnemu wzrostowi człowieka. Co ciekawe, podobne obliczenie pojawiło się w opowiadaniu Różewicza $W y$ cieczka do muzeum. Oto przewodnik (zresztą były więzień) oprowadzający grupę zwiedzających po byłym obozie koncentracyjnym w Oświęcimiu mówi: „,- Czasem wieczorami zamyślam się, proszę państwa, i robię różne obliczenia, zgładzono tu cztery miliony ludzi, więc obliczam, gdyby ustawić jednego człowieka na drugim, te cztery miliony, to utworzyłoby to wysokość sięgającą do ciał niebieskich, a gdyby ich ustawić koło siebie... [...]”. T. Różewicz, Wycieczka do muzeum [w:] idem, Proza, t. 1, Kraków 1990, s. 183. 
śladami Warłama Szałamowa. To Szałamow (w znacznie większym stopniu niż Aleksander Sołżenicyn) stał się również cicerone dla Ryszarda Kapuścińskiego, Mariusza Wilka, wreszcie - Michała Milczarka.

Milczarek Kołymę i Workutę włącza do harmonogramu swej podróży na obrzeża Rosji, wyprawy - jak głosi tytuł jego książki - „donikąd”. W tkance narracji dotyczącej rosyjskiego Wschodu dostrzec można echa dyskursów pióra poprzedników młodego reportera, jednakże da się słyszeć głos świeży, wskazujący, w sposób nieraz dosadny, na miazmaty nasyconej antywartościami przestrzeni. Dla Milczarka to podróż do „miejsc w czasie przeszłym”, miejsc, które nie mają już przed sobą przyszłości:

Było i nie ma, na Kołymie wszystko prawie było, kiedyś było, było w czasie przeszłym, a teraz nie ma, teraźniejszość jest pusta, czas teraźniejszy to rozwarta paszcza próżni, a przyszłość nie istnieje, przyszłość to tylko kolejna faza zaniku. Gnił tu trup ZSRR, rozkładały się tu zwłoki radzieckości, próchniała idea, nikt jej nie pochował, bo nikt nie miał sił [...] (Ml 120).

Sceneria „po łagrach” przeraża. Oto „kamieniste góry, śnieg i śmierć kryjąca się we wszystkich zakamarkach krajobrazu" (M1 95). Na Kołymie Milczarek dostrzega terytorium „nonsensu” i „brzydoty”, „, chaos i entropię”. Wszystko tu jest „utytłane”, siermiężne, depresyjne. Olśnienie otoczeniem, ergo zapomnienie, może być tylko chwilowe: „[p]rzez moment wydawało się nawet, że jest pięknie, że krajobraz niesie ocalenie" (Ml 96), lecz zachwycający biały puch śniegu to nie więcej niż „świeże kwiaty na grobie” (Ml 96). To mogło być zaledwie złudzenie, tutejsza natura jest bowiem - podobnie jak u Kapuścińskiego - integralną częścią historycznej traumy. Ten krajobraz:

[...] nie mógł ocalać, za dużo krwi tu wsiąkło, za dużo kul go podziurawiło, za dużo kości przyjął. Krajobraz Kołymy był skurwiony współudziałem, został wykorzystany, wplątany w morderczy system, działał jak machina do zabijania, od szkorbutu chwiały mu się zęby i miał czarne plamy po odmrożeniach (Ml 96).

W oczach Milczarka cała rosyjska Północ to wielkie składowisko śmieci, odpadków, „złomu, betonu i kości”. Jazda trasą przez kołymską surowość i przygniatającą monotonię oferuje obserwatorowi jedynie „zwłoki krajobrazu” (Ml 130). W Magadanie co prawda przyciągają oczy urokliwe, „fikuśne” (jak się wyraził) fasady stalinowskich kamienic, lecz mamy tu do czynienia z dysonansem. To jakby „ciut perwersyjne” dążenie do przezwyciężenia rzeczywistości: „to trochę tak, jakby pod obozowy drelich włożyć koronkową bieliznę" (Ml 82). Po przyjeździe do Workuty przybysz z Polski przemierza workutinskoje kol'co - pierścień na poły wymarłych osiedli otaczających miasto, zamkniętych kopalń oraz opuszczonych bloków, by finalnie stwierdzić, że ten pierścień przypomina zawieszoną na szyi pętlę. Reportera przeraża miasto 
„[s]urowe jak ochłap mięsa w rzeźni”, straszy „,[z]iemia brudna i opita krwią" (Ml 143). Milczarek postrzega ten nieczuły świat w kategoriach postapokalipsy - to „radzieckie Pompeje”. Popiół śmierć i nicość to skutek erupcji ZSRR: „Kraj zawalił się pod własnym ciężarem” (Ml 146).

Osobny passus chcę poświęcić narracji Mariusza Wilka, bo inna była historia jego zetknięcia z połagrową przestrzenią. Ciekawość świata, egzystencjalna potrzeba lub tęsknota skierowały go na Wyspy Sołowieckie, gdzie spędził kilka lat, dokumentując sprawy własne i lokalne, dla niego nierozdzielne. Wyspy stały się dla autora Wołoki w pewnym sensie ,miejscem autobiograficznym", by odwołać się do myśli Małgorzaty Czermińskiej ${ }^{21}$; a z perspektywy czytelniczej za niewątpliwy atut pisarza należałoby uznać wręcz imponującą „wyobraźnię topograficzną" ${ }^{2}$. Wilk w swoich dwóch pierwszych książkach pragnął pokazać całe spektrum sołowieckiego świata. W rozmowie ze Stanisławem Beresiem protestował przeciw nagminnemu posługiwaniu się upraszczającym według niego stereotypem: „Sołowki - łagier”. Autorowi Wilczego notesu właściwy jest - posłużę się słowami Piotra Kowalskiego - „palimpsestowy odbiór rzeczywistości" ${ }^{\prime 23}$. Z tego powodu Wilk z tak dużym naciskiem podkreśla, że łagier na Wyspach istniał „zaledwie szesnaście lat podczas gdy historia sołowieckiego klasztoru liczy sobie pięć i pół stulecia, saamskie zaś labirynty - około pięciu tysięcy lat”24. Polski podróżnik starał się zatem pokazać Sołowki z całą złożonością ich - nie tylko łagrowej - historii:

Tu, w sołowieckim klasztorze, w jego celach i kazamatach, zapisywano dzieje Rosji całymi stuleciami: na pergaminach latopisów i na kartach historii, zmieniając oblicze kraju i łamiąc charaktery inaczej myślących, przystosowując rośliny do warunków polarnych i ludzi do pracy na uwięzi (Wl.1 15).

Pisarz w pejzażu Wysp Sołowieckich próbuje odczytać zapiski poprzednich epok, rozpoznać ślady mniej czy bardziej dalekiej przeszłości tudzież objawy obecnejdestrukcji. Metodąna tojestuważna i dogłębna-czemu to miejsce szczególnie sprzyja - „kontemplacja: przyrody, historii, ludzi, zdarzen”” (Wl.1 17). Wyspy stanowią doskonały obiekt eksploracyjny, pozwalający dostrzec,

${ }^{21}$ Zob. M. Czermińska, Miejsca autobiograficzne. Propozycja $w$ ramach geopoetyki, „Teksty Drugie” 2011, nr 5, s. 183-200. Tadeusz Komendant stwierdził, że w prozie podróżniczej Wilka mamy do czynienia z ,literacką mistyką (mistyfikacją?) terytorium”. Idem, Sołowki - Wisła, „Twórczość” 1999, nr 3, s. 100-101.

${ }_{22}$ W rozumieniu Czermińskiej (Miejsca autobiograficzne, s. 188).

${ }_{23}$ P. Kowalski, O jednorożcu, Wieczerniku i innych motywach mniej lub bardziej ważnych. Szkice z historii kultury Kraków 2007, s. 45. Cyt. za: A. Zalewska, Palimpsest [w:] Modi memorandi. Leksykon kultury pamięci, red. M. Saryusz-Wolska, R. Traba, współpr. J. Kalicka, Warszawa 2014, s. 320.

${ }^{24}$ S. Bereś, Wilcza tropa. Rozmowa z Mariuszem Wilkiem [w:] idem, Historia literatury polskiej w rozmowach. XX i XXI wiek, Warszawa 2003, s. 341. 
jakie są implikacje - przywołam Schlögela - „, historii zapisywania i zamazywania symboli, zdarzeń ikonoklastycznych, w których stawką było życie lub śmierć" 25 . Wilk rozróżnia $\mathrm{w}$ pogmatwanym i wielowymiarowym obrazie Sołowek ,rękę poszczególnych twórców”: mnichów, czekistów, wojskowych, muzealników oraz „dzisiejsze bezhołowie” (Wl.1 30).

Mówiąc krótko, landszaft na Północy przypomina deskę, na której kolejne pokolenia „bogomazów” pracowicie uwieczniały swojego boga, paćkając grubą farbą, by zamalować wizerunek poprzedników, a potem jakiś kwaśny deszcz, jadowity i żrący, zmył wszystko, acz niedokładnie, zostawiając szczątki rysunku, resztki koloru (W1.1 26-28).

Ślady pozostawione na rosyjskiej Północy, choć wyblakłe i zetlałe, wywołują z niepamięci historyczne dzieje. Ze wzrokowej wyobraźni pisarza wyłaniają się skrawki nieklarownej, wieloaspektowej rzeczywistości: krzyż prawosławny, drut kolczasty, kurhan saamski, kawałek ludzkiej czaszki z dziurką od kuli, część rakiety lub podwodnej łodzi. „Pejzaż się rozmazał, wokół marazm, entropia”. W „chaosie, tym razem semiotycznym” (Wl.1 29) wybijają się najbardziej widoczne, wydobyte na powierzchnię znaki łagrowej historii. Cóż widać? „Pozostałości ze złudzeń totalitarnych XX wieku: kłęby drutu kolczastego, przegniłe wieżyczki strażnicze, ścianę baraku, czasem ludzkie kości” (W1.2 129-130). Dominujący motyw krajobrazu na Sołowkach stanowi drut kolczasty, który wykorzystywany jest do konstrukcji ogrodzeń, w okolicy dzieci bawią się w tiurmę i bywa, że w połagiernych barakach mieszkają ludzie. Liczne, bardzo oryginalne opisy malowniczości natury, wspomagane paletą środków stylistycznych, stanowią najczęściej kontrast wobec elementów „krajobrazu ludzkiego", a często same w sobie zawierają dysonanse i paradoksy bądź asocjują nieoczywiste sensy. Przykładowo: „Nad sołowieckim monastyrem wisi ciężka, granatowa tucza, purpurą oblamowana, jak wielki krwiak - pod okiem Opatrzności” (W1.2 14); czy też: „Na drzewach pojawia się młoda zieleń, puszysta i delikatna, jak jeleni scypuł; z ziemi, tłustej i nasiąkniętej, trawy wyłażą, robaki, czasem też ludzka kość, jeśli głębiej kopnąć” (Wl.1 40). Pejzaż, którego obserwatorem jest przybysz z Polski, nasycony jest cierpieniem i śmiercią, a urokliwy „landszaft” - ,jak dekoracje z innej sztuki” (Wl.1 140) - tyleż nie przystaje do siermiężnego życia - dzisiaj, ile kiedyś - do umierania w udręce. Pada pytanie, „,czy z takim widokiem przed oczyma lżej było umierać, czy trudniej?" (Wl.1 48).

${ }^{25}$ K. Schlögel, op.cit., s. 284. 


\section{2. Ślady po (cudzym) życiu}

Wilk, przemierzając ze współtowarzyszami szlak Kanału Białomorskiego i kartkując Księgę Kanału, napisaną w latach 30. przez „twórczy kolektyw” uznanych pisarzy radzieckich, wspomina, że więźniowie w trakcie prac wydobywczych natknęli się na czaszki i kości ludzkie, jak się okazało - pozostałości cmentarza z epoki kamiennej. Kamienne labirynty Saamów znalazły swój osobliwy ekwiwalent w „labiryncie z drutu kolczastego” z czasów Gułagu, zaś prehistoryczne szczątki praprzodków stanowią budulec ziemi, która jednocześnie karmi się obficie kośćmi łagierników. Relikty dalekiej czy całkiem bliskiej przeszłości, ukryte pod powierzchnią, a jednocześnie włączone w urzekającą swą urodą przyrodę, skłaniają do egzystencjalnej zadumy nad śmiercią, bo tutaj „śmierć dziwnie spotyka się z pięknem”26. Wilk co prawda wpisuje Wyspy w szeroką panoramę historyczną, eksplikując, że SŁON ${ }^{27}$ to tylko okruch ich dziejów, jednak ludzie, których spotyka, skazani zostali na życie w kontakcie z prześwitującym przez szarzyznę codzienności widmem nieodległej epoki stalinowskiej. Nieważne, że najczęściej lekceważą zakryte w ziemi ślady przeszłości. Nie chcą pamiętać - ale istnieje przecież „pamięć ziemi”"28. Autor Wilczego notesu zwraca uwagę na specyficzną biosferę w miejscu, gdzie lasy są „grzybne, jagodne i grząskie” (Wl.1 70). Groby użyźniają glebę: „Trupy grzebano na zboczach, w jagodnikach. Jagody do dzisiaj tu rosną dorodne" 29 (W1.1 48). Roma Sendyka, odwołując się do perspektywy humanistyki nieantropocentrycznej, zwraca uwagę na jeden $\mathrm{z}$ aspektów nieupamiętnionych miejsc straceń czy pochówków. Pojawia się pytanie, „w jakim stopniu przyroda staje się reprezentacją, a nawet dosłowną prezentacją w sensie uobecnienia ofiar? ${ }^{30}$. Rośliny, które czerpią

26 S. Bereś, op.cit., s. 340.

27 SŁON - skrót od Siewiernyje Łagieria Osobogo Naznaczenia (północne obozy specjalnego przeznaczenia); zob. A. Applebaum, op.cit., s. 49. Ale też: Sołowieckij Łagier Osobogo Naznaczenia; zob. N. Werth, Sołówki, laboratorium Gułagu, przedmowa [w:] S. Malsagow, N. Kisielow-Gromow, Początki Gułagu. Opowieści z Wysp Sołowieckich, przeł. M. Masny, Poznań 2019, s. 15.

${ }_{28}$ Zob. E. Konończuk, Geograficzno-historyczny aspekt procesu literackiego [w:] Kulturowa historia literatury, s. 187.

${ }^{29}$ Zuzanna Bogumił pisze o reakcjach miejscowych na odkrycie w Karelii grobów masowych ze szczątkami rozstrzelanych: „«My tutaj chodziliśmy, grzyby zbieraliśmy, a tutaj takie»”. Eadem, op.cit., s. 106. Warto w tym miejscu przytoczyć refleksję Jacka Mateckiego w wyniku jego zetknięcia z miejscami martyrologicznymi: „Ziemia tutaj dziwna, jakby zachorowała od tego światła i porosła krostami. To groby, wszędzie groby. Niektóre tak płytkie, że można potknąć się o czaszkę lub piszczel. [...] Ale za to jakie tu grzyby! Jak marzenie. [...] Miejscowi zbierają i wiozą do miasta na sprzedaż. Sami nie jedzą" (Mt 29).

${ }^{30}$ R. Sendyka, Pryzma - zrozumieć nie-miejsca pamięci (non-lieux de memoire), „Teksty Drugie” 2013, nr 1-2, s. 328. 
życie z mineralnych szczątków ludzkich, ,stają się czymś więcej niż tylko reprezentacją cierpienia ofiar - ich obecność przywraca metonimicznie byt nieobecnych" ${ }^{31}$; biotop stanowi „formę trwania ofiary" ${ }^{2}$. Z perspektywy Wilka, jak sądzę, owa bujność przyrody, która zasłania groby masowe, stanowi nawiązanie do toposu płodnej Ziemi-Matki, która w żyzną glebę i nowe życie zamienia martwą materię ${ }^{33}$.

Notabene nie bez powodu w polskiej prozie z rosyjskiej Północy pojawiają się też wzmianki na temat aktualnych pochówków tubylców. Najwięcej miejsca pisarz poświęca samobójczej śmierci poetki Antoniny Mielnik - postaci ważnej nie tylko w życiu Sołowek (w muzeum sołowieckim zajmowała się SŁON-em jeszcze przed „,modą na łagry”), ale także kluczowej dla jego osobistej „rosyjskiej inicjacji”. Mielnica, inicjatorka usypania przez dzieci i wnuki ofiar Gułagu „grobu nieznanego zeka” - z kamieni, bo w kamieniach żyją duchy przodków - choć przyjezdna, na dobre przylgnęła do miejsca, gdzie „ściany płaczą, grzyby rosną na trupach” (W1.1 135-140):

Parę razy próbowała stąd uciec, raz nawet na Kołymę ją zaniosło. Ale wracała, bez Sołowek żyć już nie mogła. Sama nie wie, kiedy poczuła, że Wyspy i ona to jedno, że ich ziemia to jej skóra (pod którą zaryto trupy), a ich dzieje to jej życie (Wl.1 141).

Można rzec, że jednym z motywów przewodnich relacji polskich podróżników z miejsc stanowiących swoiste media pamięci o łagrach są kości. Michał Milczarek tym właśnie słowem zatytułował rozdział swej książki poświęcony podróży na Kołymę. Już na pierwszym etapie wyprawy w te strony reporter stwierdza z gorzką ironią, że „,[ż]ycie w Magadanie się nie udało, trochę lepiej udała się śmierć” (Ml 82). Śmierć niewątpliwie „udała się” w głębi pokrytego niegdyś łagrami lądu i na samej Trasie. „To musiało gdzieś zostać, [...] bo jeśli się wydarzyło, to tym samym jest, jest już na zawsze" (M1 76-77) - konstatuje Milczarek, który bez ustanku podkreśla szczególną, bo „trupią”konstytucję tej ziemi. Mamy więc: „kościstą drogę”, „kościstą pustkę”, „kościstą ziemię”. Przemierzanie Kołymy oznacza jazdę „kość za kością", a czekanie na autostop wiąże się z „wydeptywaniem ścieżki pośród kości”. To dla reportera obszar iście fantazmatyczny, bo przecież nie chodzi o konkretne zetknięcie ze szczątkami ludzkimi. Cmentarność kołymskiej

31 Ibidem, s. 329.

32 Ibidem, s. 330.

33 Zob. ibidem, s. 334. Jacek Leociak, odwołując się do jednego z opowiadań Szałamowa (Z lend-lease'u [w:] idem, Opowiadania kołymskie, przeł. J. Baczyński, wyd. 3 popr. (dodruk), Poznań 2017, s. 719-725), pisze o „metaforze rezurekcyjnej” - gdy ziemia odsłania swoje wnętrze i oddaje sprawiedliwość ofiarom. Idem, Doświadczenia graniczne. Studia o dwudziestowiecznych formach reprezentacji, wyd. 2 popr., Warszawa 2018, s. 306-310, cyt. s. 308. 
przestrzeni, kumulująca się zwłaszcza w strefie Traktu Kołymskiego - tego „,najdłuższego cmentarza świata” - eksponowana jest też w prozie reportażowej Hugo-Badera:

[T]a licząca ponad dwa tysiące kilometrów droga wybrukowana jest ludzkimi żywotami. Położona na kościach. I to nie jest żadna metafora. Bo niby dlaczego wzdłuż całej Trasy nie ma ani jednego starego cmentarza?

Dlatego, że zmarli leżą kilkadziesiąt centymetrów pod powierzchnią drogi. Tysiące ludzi. Praca przy budowie Traktu to obok kopania złota była najgorsza robota na Kołymie. Kto przy niej padł, z tego ściągali obozowe łachy (jeszcze się przydadzą), obracali twarzą do góry i przykrywali kołymskim gruntem, z którego usypana jest Trasa (HB 115-116).

Reporter pozwala sobie na szczyptę czarnego humoru, pisząc o dyskomforcie związanym z fizjologiczną potrzebą: „O czym przez pierwsze dni podróży myślę najmocniej? Jak tu się odlać? Wychodzę z samochodu, a w czaszce mi świdruje, że jakiemuś biedakowi sikam na głowę" (HB 116) (H4 $^{34}$ Wyobraźnia wiąże się w tym wypadku ze słusznym uprzytomnieniem sobie faktów. „Rzecz w tym, że stoimy na ludzkich kościach - konstatuje Kapuściński w Magadanie. - I gdyby nawet pod wpływem tej świadomości odskoczyć na krok albo nawet odbiec na kilkaset metrów, niczego to nie zmieni: wszędzie cmentarz i cmentarz" (Kp 203). Esencją ziemi na skraju Rosji, w miejscach dawnych łagrów są zatem szczątki ludzkie i to reporterzy starają się eksponować, nie odżegnując się od hiperbolizacji. Wystarczy zacytować Jacka Mateckiego, który stwierdza: „Pół Rosji zbudowano na kościach. Gdzie koparka wbije łychę, tam czaszki” (Mt 25). Wojciech Grzelak nie obawia się nazywać rzeczy po imieniu, pisząc o godzącym w istotę praw człowieczeństwa skandalu - odmówieniu ofiarom prawa do ludzkiego pochówku: „Kości wielu z nich poniewierają się do dziś na śmietniskach, spoczywają pod fundamentami nowych osiedli i nawierzchnią szos, żółkną w tajdze rozwleczone przez dzikie zwierzęta" (Grz 179). Martwe ciała, de facto resztki szkieletu zabitych lub zmarłych z głodu i wycieńczenia więźniów Gułagu, stanowią świadectwo zbrodni, materiał dowodowy, choć nie o „materialność" chodzi, ale o ,ślad bytu" 35 .

Autor Dzienników kołymskich, rzec można, epatuje drastycznymi motywami i opisami związanymi z naruszeniem tabuistycznych zakazów. Już na początku relacji wspomina o krążących wśród kołymian przekazach na

${ }^{34}$ Motyw nieświadomego deptania zmarłych pojawia się u Jacka Mateckiego, gdy pisze o pogrzebanym nie wiadomo dokładnie, w którym miejscu, aktorze Eugeniuszu Bodo (Zob. Mt 20).

35 Zob. E. Domańska, Historie niekonwencjonalne. Refleksja o przeszłości w nowej humanistyce, Poznań 2006, s. 188. 
temat smaku ludzkiego mięsa. Gdzie indziej przedstawia postać właściciela firmy zajmującej się poszukiwaniem złota, który w czasach radzieckich skierowany został do prac geologicznych na terenie dawnego „rasstrielnego" obozu śledczego, co oznaczało „straszną robotę, babranie w ludzkich resztkach" (HB 146) na terenie, gdzie kombajny do płukania złota zamieniły się w gruncie rzeczy w maszyny do mięsa. Dla Władimira Augustowicza Najmana, bohatera reportażu, doświadczenie to okazało się tyleż traumatyczne, ile przełomowe. W tym, co wówczas i później nastąpiło, odczytał znaki dane przez Boga. Jego misją życiową stało się stawianie na ,zekowskich” cmentarzach krzyży, które upamiętniać mają zmarłych łagierników. Inny napotkany przez reportera mężczyzna, trudniący się wydobyciem złotego kruszcu, wspomina sytuację z początku lat osiemdziesiątych XX wieku, gdy koparką „wyry”" z ziemi prawie nietknięte ludzkie ciało więźnia ${ }^{36}$ - w łagrowym ubraniu z zaświadczeniem o zwolnieniu z katorgi w kieszeni. Zwłoki zabitego - być może sprawcami byli koledzy lub strażnicy - mężczyzny odebrała jego mieszkająca pod Moskwą siostra. Dopiero teraz, po upływie kilkudziesięciu lat możliwe było należne każdemu człowiekowi godne pogrzebanie ciała oraz usankcjonowanie prawa do osobnego grobu i „unieśmiertelniającego" nagrobka.

„Trup-rzecz czy trup-osoba" ${ }^{37}$ - stawia problem antropolog Louis-Vincent Thomas, a polscy reporterzy zwracają przede wszystkim uwagę na uprzedmiotowienie i degradację pośmiertną ofiar stalinizmu pozbawionych prawa do ludzkiego pochówku, oznaczającego szacunek dla ich osobności. Wymownym tego przykładem jest następujący opis:

Kładło się zmarłych w szeregu na zboczu i zasypywało ziemią znad ich głów. Tak powstawał niewielki taras, na którym układało się następny szereg, który zasypywało się ziemią z jeszcze wyższej partii. Cmentarz, na który przyszliśmy, ma jedenaście tarasów długości około 130 metrów. Łatwo policzyć, ilu tu leży nieszczęśników (HB 147-148).

Warto w tym miejscu przywołać poruszający opis (pióra francuskiego filozofa), obnażający „treść” i „fizjonomię” masowych grobów:

W zbiorowym grobie ciała pomordowanych nie są ciałami zmarłych, nie są naszymi zmarłymi, lecz ranami poukładanymi w sterty, pozlepianymi, przelewającymi

${ }^{36}$ Mowa tu o zachowaniu nietkniętych zwłok w ,wiecznej zmarzlinie”. Do tego obecnego w opowiadaniach Szałamowa motywu często nawiązywali polscy reporterzy. „Zresztą ich zwłoki pozostaną niezniszczalne - zmarli wiecznej zmarzliny”. W. Szałamow, Spisek prawników [w:] idem, Opowiadania kotymskie, s. 185.

${ }^{37}$ L.-V. Thomas, Trup. Od biologii do antropologii, przeł. K. Kocjan, Łódź 1991, s. 100 . 
się jedne w drugie; i ziemia zrzucana prosto w dół - tam, gdzie żaden całun nie oznacza przestrzeni przysługującej jednemu zmarłemu, innemu zmarłemu ${ }^{38}$.

Zbiorowe grzebanie zmarłych (zwłaszcza straconych) w bratskich mogiłach (rosyjska nazwa brzmi szczególnie wymownie) godzi w podstawowe humanistyczne wartości, prowadzi bowiem do niwelowania indywidualności egzystencji ludzi, którym śmierć odebrała ,nie tylko życie, odebrała im także tożsamość ich życia"39. Grozę budzi „taśmowość” anonimowych zgonów, a czynione - na przykład przez Hugo-Badera - rachunki i przeliczenia, mające uprzytomnić skalę ludobójstwa, odsłaniają jedynie bezduszność statystyk, bo przecież - „historia zaokrągla szkielety do zera”, o czym przypomniała Wisława Szymborska w jednym z wierszy (Obóz głodowy pod Jasłem z tomu Sól, 1962). Oto co pisał na ten temat Aleksander Sołżenicyn:

Dzielimy, mnożymy, wzdychamy, przeklinamy. Ale to w końcu cyfry. Naprzód człowiek słupieje, później zapomina. Gdyby zaś kiedyś krewni rozstrzelanych złożyli w jednym jakimś wydawnictwie fotografie swoich pozabijanych bliskich, i gdyby później wydany został album tych zdjęć, kilka tomów takiego albumu - to wertując go i darząc ostatnim spojrzeniem te zgasłe oczy, moglibyśmy nie byle jak wzbogacić resztę naszego życia. [...] Zostałaby nam wtedy chociaż mała szrama na sercu po tych zgonach ${ }^{40}$.

Za swego rodzaju odzew na słowa pisarza można uznać przejmujący album Tomasza Kiznego. Odzew to szczególny, bo na książkę składają się zrobione w ramach śledczej procedury fotografie niektórych ofiar terroru stalinowskiego zachowane w archiwach NKWD.

Fotografie ofiar wielkiej czystki są czymś na podobieństwo masek pośmiertnych, które zdejmowano z twarzy zmarłego, by zachować odcisk jego oblicza, z tą różnicą, że zostały „zdjęte” za życia, czasem zaledwie kilka godzin przed śmiercią. Wbrew intencjom oprawców, którzy skazywali ofiary nie tylko na śmierć, ale także na zapomnienie, dzisiaj te fotografie przywołują [...] pamięć tych, którzy mieli zniknąć na zawsze „bez prawa korespondencji”41.

38 J.-L. Nancy, Corpus, przeł. M. Kwietniewska, Gdańsk 2002, s. 70.

39 J. Kolbuszewski, Cmentarze, Wrocław 1996, s. 11.

40 A. Sołżenicyn, Archipelag GUŁag 1918-1956. Próba dochodzenia literackiego, cz. I-II, przeł. J. Pomianowski (M. Kaniowski), Warszawa 2000, s. 443.

${ }^{41}$ T. Kizny, Damnatio Memoriae [w:] T. Kizny, współpr. D. Roynette, Wielki Terror 1937-1938, Warszawa 2013, s. 25. 
Te fotografie w istocie uznać można - posługując się określeniem Susan Sontag - za „świeckie ikony”42, pogłębiające odczucie osobistego wymiaru tragicznych dziejów. Zdjęcia ogromnej części zabitych lub zamęczonych zachować się mogły tylko w rodzinnych albumach. Tylko czy ktoś do nich zagląda?

\section{Pejzaż mentalny}

Dla Michała Milczarka pobyt w Magadanie, twarzą w twarz z „,sinym i złowrogim" Morzem Ochockim, staje się asumptem do przypomnienia zrelacjonowanej w jednym z opowiadań Warłama Szałamowa historii parowca Kim statku, który przypłynął na Kołymę z Władywostoku na początku grudnia 1947 roku „Z zamarzniętym ładunkiem ludzkim” (trzy tysiące więźniów) na pokładzie. Reporter poniekąd parafrazuje suche a dojmujące słowa rosyjskiego pisarza ${ }^{43}$ :

Ów ladunek ludzki po drodze wszczął bunt, więc podjęto decyzję o zalaniu go wodą przy minus czterdziestu. Martwych wyładowywano na brzeg, a potem jak bryły lodu przerzucano na ciężarówki, które woziły ich do bratnich mogił. Do ciał nie przywiązywano żadnych metek, które świadczyłyby, że ktoś miał imię, nazwisko i datę urodzenia, trupów było za dużo, nikt nie miał czasu na ewidencję. Zamarznięta ziemia wchłaniała zamarzniętych ludzi, tak jakby nigdy nie istnieli (Ml 80).

„Jakby nigdy nie istnieli” - dotyczy też łagierników pochowanych w Workucie, których mogiły oznaczone numerami zamiast nazwisk miał okazję widzieć autor Donikad. Osoby te zostały odarte nie tylko z godności i praw ludzkich, lecz także z biografii, „,[d]latego istotne staje się pamiętanie, że każda ofiara to konkretne i niepowtarzalne życie oraz konkretna i niepowtarzalna śmierć" ${ }^{44}$.

Krystyna Kurczab-Redlich gorzko (i uogólniająco) konstatuje, że Rosjan charakteryzuje lekceważący stosunek do śmierci, co przekłada się również na ich odniesienie do przodków: „Dziwiło mnie na przykład to, że większość nie

${ }^{42}$ S. Sontag, Widok cudzego cierpienia, przeł. S. Magala, Kraków 2010, s. 141. W muzeum Auschwitz na ścianach jednego z bloków umieszczone zostały fotografie zamordowanych i zmarłych: „Twarze. Wiszą w mrocznym korytarzu. Patrzą w dzień i w nocy. W nocy, kiedy w muzeum nie ma ludzi. Twarze ich bez przerwy wydzielają cierpienie, którego już nie ma w muzeum”. T. Różewicz, Wycieczka do muzeum, s. 187.

${ }^{43}$ Do tego samego opowiadania nawiązuje autor Imperium (Kp 205).

${ }^{44}$ B. Darska, Pamięć codzienności. Codzienność pamiętania. Szkice o reportażu polskim XXI wieku, Gdańsk 2014, s. 217 (przypis 31). 
interesuje się, gdzie zginęli, jak umierali..." ${ }^{\text {45 }}$. Nie chcą wiedzieć, czy bliscy byli sprawcami czy ofiarami. Nieistotne staje się również miejsce ich pochówku. W relacjach polskich podróżników pojawiają się wzmianki na temat zaniedbanych „cywilnych” cmentarzy rosyjskich. Reporterzy próbują przybliżyć się do osobliwej logiki Rosjan:

Nikt tu chyba nie przywiązuje nadmiernej wagi do wyschłej i martwej miazgi życia. Śmierć była zawsze zbyt blisko Rosjan. Umarł to umarł - nic nie poradzisz. Był to był: kochaliśmy go, nienawidziliśmy, piliśmy z nim wódkę, pracowali, żyli, śmiali się i cierpieli. Teraz już go nie ma. Nas też za chwilę nie będzie. Co za różnica, gdzie złożysz, w jaki dół wrzucisz na zgnicie mięso i kości? (JiM 183).

Brytyjczyk Jeremy Poolman najpierw z zaskoczeniem reaguje na rosyjski stosunek do obowiązku pamięci o tych, którzy odeszli, by za chwilę stwierdzić z rezygnacją, a raczej z pewną prowokacją:

Nagle pojawiła się mrożąca myśl, że może on ma rację - że może zmarli po prostu odchodzą, że ożywianie ich pamięci jest zarówno bezużyteczne dla żywych, jak i nieprzydatne dla zmarłych, i z pewnością zakłóca spoczynek ciał w cichym, dalekim grobie ${ }^{46}$.

Punktu widzenia tubylców próbował domyślić się Michał Milczarek:

Kiedyś był tu łagier, ale nie wiadomo gdzie dokładnie, [...], łagry wymazano z pamięci, bo zmieniły się czasy, gdzieniegdzie stoi tylko jakiś pomnik albo krzyż, i to by było na tyle, ludzi generalnie to nie obchodzi, po co do tego wracać, co nam to da, my tu żyjemy i po co mielibyśmy zatruwać to życie śmiercią, takie były czasy, a potem się zmieniły, więc po co wracać do tamtych czasów, skoro już ich nie ma (Ml 116).

Nie sposób nie zauważyć, że mamy tu do czynienia z pewnymi generalizacjami, co grozić może stereotypizacją. Niemniej jednak pewien rys mentalności tubylców, tak czy inaczej uwarunkowanej, został uchwycony. Stosunek mieszkańców części Federacji Rosyjskiej do śmierci łagierników i innych ofiar stalinowskiego terroru oraz nieposzanowanie miejsc cierpienia $i$ - choć zabrzmi to eufemistycznie - miejsc spoczynku nabierają cech szczególnych. Niepochowane lub ,źle pochowane" ${ }^{47}$ ciała domagają się odprawienia rytu-

${ }^{45}$ K. Kurczab-Redlich, Lekcje rosyjskiego [w:] P. Brysacz, J. Morawiecki, Ani żadnej wyspy. Rozmowy o Rosji i Ukrainie, Białystok 2016, s. 60.

46 J. Poolman, Droga z kości. Podróż do mrocznego serca Rosji, przeł. J. Grzegorczyk, Poznań 2012, s. 37.

${ }^{47}$ R. Sendyka, Miejsca, które strasza..., s. 299. 
ałów i należytego pogrzebu. Roma Sendyka przypomina w swym artykule ponadkulturową i ponadczasową zasadę, która mówi, iż ,niedopełnienie zasad ustanowienia symbolicznej i fizycznej bariery między żywymi a umarłymi może spowodować, że duch pozostanie [...], żądając swoich praw do rytuału przejścia" ${ }^{48}$. W polskich relacjach niespokojne, nieukojone duchy strasznych miejsc przypominają o swojej obecności. Czy nie tak należy odczytywać passus z książki Milczarka o śnie czy nie-śnie, jaki przydarzył mu się pierwszej nocy w Magadanie, ze zwidem brnącego przez śnieżną zamieć człowieka? Czy nie tak trzeba by spojrzeć na widzenie senne Wilka w związku ze zwiedzaniem Kanału Białomorskiego: „Śni mi się gigantyczna jama, niczym rozwarty brzuch ziemi, na dnie pełzają ludzie śród grud błota, błotem umazani, i trudno rozróżnić, gdzie człek, gdzie gruda, jeno po pełzaniu" (W2 102-103)? W Imperium wizja powrotu zmarłych Workuty - pochodu szkieletów w łachmanach - włączona została w rozważania nad ideą rosyjskiego filozofa i wizjonera dotyczącą wskrzeszenia zmarłych. „Mikołaj Fiodorow marzył, żeby ich wszystkich przywrócić życiu. Ale - jakiemu życiu?” (Kp 165) - zapytuje reporter ${ }^{49}$. Inaczej kwestia duchów wygląda w Dziennikach kotymskich. Wspominana już, mieszkająca na stałe w Paryżu emigrantka, córka łagiernika wyznaje dziennikarzowi, że rozmawia z nieżyjącym ojcem i innymi umarłymi. Oto na Kołymie dane jest jej doświadczać niesamowitej energii, która „[b]ije tu z każdego wzgórza, każdej płyty chodnikowej jakby słup światła”, czuje „wszystkie kości, które tutaj leżą, krew co wsiąkła w ziemię. [...] Dobre duchy czuwają nad tą ziemią" (HB 102). Przedziwna dywagacja. Z kolei inny bohater książki Hugo-Badera nieupamiętnione miejsca pochówku łagierników wyróżnia krzyżami. ,[P]rzy stawianiu krzyży zupełnie przestajesz być ziemską istotą. Stajesz się duchem. Łączysz się ze wszystkimi umarłymi, nad którymi stawiasz te dwa kawałki drewna" - powiada.

Gustaw Herling-Grudziński w Innym świecie z perspektywy osobistych doświadczeń pisał o lęku więźniów przed zupełnym unicestwieniem:

Świadomość, że nikt nigdy nie dowie się o ich śmierci i o tym, gdzie ich pochowano, była dla więźniów jedną z największych tortur psychicznych. Można być człowiekiem niereligijnym, nie wierzyć w życie pozagrobowe, ale trudno pogodzić się z myślą, że raz na zawsze wymazany zostanie jedyny materialny świat, który przedłuża istnienie ludzkie i nadaje mu wyrazistą trwałość w pamięci ludzkiej.

${ }^{48}$ Ibidem, s. 301. Autorka odwołuje się do: Ch. Quigley, The Corpse: A History, Jefferson, NC 2005, s. 15-17.

${ }^{49}$ Przychodzi w związku z tym na myśl przejmujący wiersz Broniewskiego o pochodzie zabitych żołnierzy wielkiej wojny: Ostatnia wojna [w:] idem, Poezje 1923-1961, wybór i wstęp W. Woroszylski, Warszawa 1995, s. 52-58. 
[O]bóz sowiecki pozbawił miliony swoich ofiar jedynego przywileju, jaki dany jest każdej śmierci - jawności - i jedynego pragnienia, jakie odczuwa podświadomie każdy człowiek - przetrwania w pamięci innych ${ }^{50}$.

Gdy więźniowie ukarani na podstawie artykułu 58 (dotyczącego zbrodni kontrrewolucji) tracili życie, rodzina nie dowiadywała się nawet o fakcie ich śmierci, a cóż mówić o przekazaniu informacji o ,lokalizacji” szczątków. Mamy tu do czynienia - powtórzę za Ewą Domańską - z ,instytucją znikniętych" "51 i podwójną nieobecnością zaginionych: wśród żywych i wśród zmarłych. „Liminalny stan zaginionych"52 uniemożliwia opiekę nad dopełnieniem istnienia zmarłego ${ }^{53}$, staje na przeszkodzie odbyciu żałoby niwelującej „niszczącą moc zgonu"54 i udaremnia opłakiwanie, które służyło od wieków przekształceniu zmarłego w przodka: „Dopiero wtedy - pisze włoski antropo$\log$ - chaos uczuć cechujący stosunki żywych ze zmarłym zostaje ostatecznie uspokojony, a faza opłakiwania zamknięta" ${ }^{55}$. W tym wypadku zastrzec należy, że „zniknięci” nie zawsze byli poszukiwani, a „nieobecni” niekoniecznie stawali się ,brakującymi”"56.

W przypadku ofiar stalinowskich w Rosji ,status nieopłakanych” ma związek z brakiem pamięci o nich w różnych jego wymiarach, bo jak pisze Czermińska, zapomnienie ,[m]oże być ujmowane ze znakiem ujemnym, jako strata lub zdrada, albo ze znakiem dodatnim, jako wyzwolenie od martwego ciężaru lub uleczenie traumy" ${ }^{57}$. Chciałabym się skupić na tym drugim aspekcie. O ,prawie koniecznego zapominania" 58 pisał Paul Ricoeur, zaś Marc Augé w odniesieniu do traumatycznych wydarzeń historycznych - podkreślał, że ci, którzy ocaleli, aby żyć od nowa, „muszą mieć swój udział w zapomnieniu,

${ }^{50}$ G. Herling-Grudziński, Inny świat, Warszawa 1989, s. 198-199.

${ }^{51}$ E. Domańska, op.cit., s. 183.

${ }^{52}$ Ibidem, s. 188

53 Ibidem, s. 171. Domańska odwołuje się do pracy M. Heideggera (Bycie i czas, przeł. B. Baran, Warszawa 1994, s. 332-354).

${ }^{54}$ A.M. di Nola, Tryumf śmierci. Antropologia żałoby, red. M. Woźniak, przeł. J. Kornecka et al., Kraków 2006, s. 10.

${ }^{55}$ Ibidem, s. 24. Zuzannna Bogumił opisuje, jak bliscy zamordowanych z miejsca rozstrzeliwań czynią ,przestrzeń odzyskiwania historii własnej rodziny” i stosują ,zastępcze sposoby oddawania czci zmarłym”; wobec „syndromu zagubionego grobu” i „,bezdomnej śmierci" tworzą symboliczne mogiły i cmentarze. Eadem, op.cit., s. 115-116.

${ }^{56}$ R. Sendyka, Miejsca, które strasza ..., s. 303.

${ }^{57}$ M. Czermińska, Tożsamość..., s. 146.

${ }^{58}$ P. Ricoeur, Pamięć - zapomnienie - historia, przeł. J. Migasiński [w:] Tożsamość w czasach zmiany. Rozmowy w Castel Gandolfo, przedm. i oprac. K. Michalski, Kraków 1995, s. 38. Wątek ten podejmuje też Elena Esposito, Soziales Vergessen. Formen und Medien des Gedächtnisses der Gesellschaft, transl. A. Corti, Frankfurt am Main 2002. Esposito posługuje się pojęciem „społecznego zapominania”. Tę pozycję bibliograficzną wskazała mi Barbara Kaszowska-Wandor. 
[...] aby odnaleźć raz jeszcze wiarę w codzienność i umieć panować nad swoim czasem"59. Tyleż intrygujący, ile budzący zaskoczenie Hugo-Badera sentyment wielu miejscowych do „rodzonej, kochanej Kołymy”, co oznacza de facto życie na miejscu cierpienia i kaźni, można oceniać afirmatywnie. Pisała na ten temat Bernadetta Darska:

Jeśli dawne ofiary rozpamiętywałyby swój los, a także tych, którym nie udało się przetrwać, przeszłość przyciągałaby je tak mocno, że niemożliwe stałoby się emocjonalne zagospodarowanie teraźniejszości. Może więc właśnie życie - wbrew wszystkiemu i wszystkim - okazuje się najdoskonalszym orężem przeciwko triumfowi śmierci, pogardy, zniewolenia? [...] [I]ch wolność polega na tym, że nie muszą uciekać od Kołymy. Wszechobecność śmierci dzięki ich decyzji zostaje przynajmniej częściowo odczarowana. [...] Skoro dawni więźniowie mogą mieszkać w sąsiedztwie dawnych łagrów, ich mroczna siła zostaje częściowo unieważniona ${ }^{60}$.

Anne Applebaum podczas rekonesansu czynionego na terenach dawnych łagrów spotykała się z niechętnymi reakcjami wielu mieszkańców: „Dlaczego was, cudzoziemców, interesuje zawsze tylko to, co złe w naszej historii?" „Dlaczego nie pisze pani o naszych prawdziwych problemach zamiast o rzeczach, które wydarzyły się tak dawno temu?” „To nie pani interes”, „To już nie ma znaczenia" ${ }^{\prime \prime}$. Polscy podróżnicy z zainteresowaniem przypatrują się temu, jak toczy się w przestrzeni post mortem życie zarówno tych, którzy zapuścili tu korzenie, zżyli z krajobrazem i pragną tu spocząć po śmierci, jak i tych, którzy zostali, bo nie mają jak i gdzie wyjechać, zostali niejako skazańcami. Co ciekawe, wśród mieszkańców terenów połagrowych znajdują się ludzie, którzy przybyli tutaj dobrowolnie z innych zakątków Rosji, na przykład Warwara, córka łagiernika, która „po śladach ojca trafiła na Sołowki” i tutaj się osiedliła (W1.1 19), czy „pomylony Grisza, syn giebisty z Murmańska”, który przywędrował na Wyspy po przeczytaniu Sołżenicyna: „A kiedy poczuł, że mu się ziemia spod nóg osuwa, uwierzył w Boga i zaczął pić. Po pijanemu, bywa, z Eichmansem ${ }^{62}$ gada, a niekiedy sam się Eichmansem mieni” (Wl.1 47). Nieopodal Magadanu zamieszkała bohaterka relacji Hugo-Badera - Natalia,

${ }^{59}$ M. Augé, Formy zapomnienia, przeł. A. Turczyn, wstęp J. Mikułowski-Pomorski, Kraków 2009, s. 89.

${ }^{60}$ B. Darska, op.cit., s. 255-256.

${ }^{61}$ A. Applebaum, op.cit., s. 513, 514.

${ }^{62}$ Fiodor Eichmans (1897-1938) - naczelnik SŁON, funkcjonariusz OGPU/NKWD, stracony podczas wielkiej czystki. Jest on prototypem postaci Eichmanisa w Klasztorze Zachara Prilepina. 
przybrana córka Nikołaja Jeżowa ${ }^{63}$, która dobrowolnie i bezwiednie jako miejsce pracy wybrała Kołymę. „Nie wyobrażacie sobie, ilu ludzi mi opowiada, że przyjechali tu, uciekając najdalej jak się da" - komentuje jej zaskakującą decyzję reporter (HB 72).

Autor Dzienników kołymskich, dostrzegający w mieszkańcach tej ziemi „[d]ziwne, zahibernowane przez morderczy kołymski klimat sowieckie ponuractwo" (HB 50), odróżnia prawdziwych kołymian, ,ludzi starych zasad” (HB 207), czyli synów lub wnuków byłych zeków oraz tych, którzy dziesiątki lat temu zapuścili tu korzenie, od ludności napływowej - „wriemienszczików", którzy przyjeżdżają tu tylko po to, żeby się wzbogacić. Lecz - jak się okazuje - i jedni, i drudzy mają problem z pamięcią. Co boli, zwłaszcza w przypadku młodszego pokolenia, bo przecież - jak pisał francuski antropolog - umożliwiająca w miarę normalnie funkcjonowanie - „konieczność zapomnienia” nie dotyczy potomków ofiar, a ich „obowiązek pamięci” wiąże się z ,imperatywem wspominania i czuwania" ${ }^{64}$. Hugo-Bader podczas pobytu w obwodzie magadańskim nie uzyskuje od miejscowych wskazówki, gdzie był obóz: „Dlaczego ich to kompletnie nie obchodzi? [...] O tym powinni uczyć w tutejszych szkołach, bo na Kołymie każda szkoła jest koło jakiegoś byłego obozu. Tam siedzieli i umierali niewinni ludzie, ich dziadkowie [...]" (HB 213). O kaleczących psychikę zaszłościach historycznych, o mechanizmach obronnych Rosjan, a wreszcie o brakach (i przekłamaniach) w edukacji historycznej Rosjan i polityce historycznej obecnych władz w Rosji wypowiadało się wielu polskich podróżników czy ludzi odwiedzających cyklicznie ten kraj. Skutkiem tych procesów stała się - jak konstatował Maciej Jastrzębski „niemożność wzajemnego zrozumienia się" ${ }^{95}$.

Hugo-Bader nie może pojąć, dlaczego w centrum Magadanu - i to w szczytowym okresie pieriestrojki - umieszczono okazały monument z popiersiem ,jednej z najbarwniejszych postaci w całej historii Gułagu" ${ }^{\prime 66}$, pierwszego komendanta obozu na Kołymie - Eduarda Berzina: „To mniej więcej tak, jakby w Oświęcimiu postawić pomnik znakomitego lekarza i antropologa Josefa Mengele albo zasłużonego chemika, który wymyślił cyklon B" (HB 51). Porównanie reportera wydaje się nietrafione. Berzin (notabene stracony podczas wielkiej czystki 1938 roku) względnie - jeśli można tak się wyrazić - humani-

${ }^{63}$ N. Jeżow - szef służby bezpieczeństwa i ,symbol stalinowskiego horroru”. Za jego czasu terror (tzw. czystki) przyjął globalny charakter, a okres represji nazwano ,,jeżowszczyzną". Oskarżony o szpiegostwo i rozstrzelany w 1940 roku. Zob. G. Przebinda, J. Smaga, Kto jest kim w Rosji po 1917 roku. Leksykon, Kraków 2000, s. 125-126.

${ }^{64}$ M. Augé, op.cit., s. 89-90.

${ }^{65}$ M. Jastrzębski, Wypalanie traw przez opozycje [w:] P. Brysacz, J. Morawiecki, Ani żadnej wyspy..., s. 189. Kwestie dotyczące różnych aspektów (nie)pamięci Rosjan podjęłam w artykule: Rosja - między pamięcią a zapomnieniem...

${ }^{66}$ A. Applebaum, op.cit., s. 104. 
tarnie traktujący łagierników (choć przecież tylko część więźniów korzystała ze szczególnych przywilejów), zyskał sobie szacunek tubylców jako dyrektor trustu Dalstroj. Co prawda w wypełnianiu swych obowiązków stosował się do zaleceń Stalina, ale wprowadził też własne reguły, toteż jego epokę - jak pisze Anne Applebaum - wspominano z nostalgią:

Berzin wydawał się pojmować swoje zadanie w sposób zupełnie dosłowny: jego praca polegała na zmuszeniu więźniów do wydobycia jak największej ilości złota. Nie interesowało go ich głodzenie, karanie i zabijanie, liczyły się statystyki wydobycia. Być może dlatego pod rządami pierwszego szefa Dalstroju warunki panujące w obozach nie były nawet w połowie tak surowe, a więźniowie tak wygłodniali, jak kilka lat później ${ }^{67}$.

Mieszkańcy cenili go za wysiłek, jaki włożył w ucywilizowanie dzikich przecież rejonów: „Gdyby nie było Dalstroju, nie byłoby Magadanu, trasy kołymskiej, wiosek i osad znajdujących się na jej drodze - małych ojczyzn

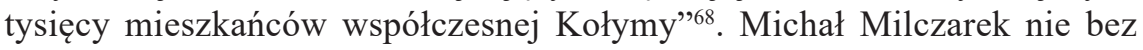
ironii nadmienił, iż ,[n]aród dobrze wiedział, że naczelnicy łagrów mogli być dobrzy lub źli, a dobry łagier to nie to samo co zły łagier, zatem dobry naczelnik dobrych łagrów zasługuje na popiersie na głównym placu stolicy łagrów" (M1 82). Tutaj historia nigdy nie była czarno-biała, bo jak konstatuje - dostrzegający niezrozumiałe dla obcokrajowców lub lekceważone przez nich detale - Arsienij Roginski:

W sowieckim terrorze nie było łatwo oddzielić oprawców od ofiar. [...]

[W] odróżnieniu od nazistów, którzy generalnie rzecz biorąc, zabijali „obcych" - Żydów, Polaków, Rosjan - w Rosji zabijano głównie swoich. [...] W pamięci o terrorze, w naszych opowieściach o nim nie jesteśmy w stanie obsadzić głównych ról, nie jesteśmy w stanie określić położenia zaimków „my” oraz „oni”. Ta niemożność wskazania zła stanowi główną przeszkodę w konstruowaniu historycznego obrazu Wielkiego Terroru. Co więcej, wzmacnia traumatyczny charakter tego doświadczenia. I jest jedną z najważniejszych przyczyn wypierania go na peryferie świadomości ${ }^{69}$.

${ }^{67}$ Ibidem, s. 107. Autorka jako argument podaje fragment opowiadania Warłama Szałamowa. Zob. W. Szałamow, Zielony prokurator [w:] idem, Opowiadania kołymskie, s. 372-373. Jednak narrator innej opowieści konstatuje: „Legenda o Berzinie [...] wybujała w przepyszny kwiat przesady”. W. Szałamow, U strzemienia, przeł. A. Pomorski [w:] idem, Procurator Judei i inne utwory, wybór L. Budrecki, Warszawa 1991, s. 90.

${ }^{68}$ Z. Bogumil, op.cit., s. 302

${ }^{69}$ A. Roginski, Pamięć o stalinizmie, przeł. A. Sowińska [w:] T. Kizny, współpr. D. Roynette, Wielki Terror..., s. 16-17. Rosyjski historyk Aleksander Etkind podkreślał: „Jesli naciststkij Chołokost unicztożał Drugogo, to sowietskij terror był pochoż na samoubijstwo". Idem, Kriwoje gorie. Pamiat'o niepogriebiennych, pieriew. W. Makarow, 
W tym kontekście nic dziwnego, że związane z transformacją próby rozliczenia historii wywołały co najmniej zaniepokojenie i konsternację. „Skoro ja przeżyłem, nie było tak źle” (Mt 26); „On w polityce się nie wyznawał. On służył...” (W1.2 45); „Wtedy wszyscy trud szanowali, dyscyplinę trzymano, nie to co dziś" (W1.2 48) - tak brzmią niektóre argumenty Rosjan. Pochodząca z represjonowanej rodziny nauczycielka historii, której wypowiedź przytaczają Jastrzębski i Morawiecki, choć prowadzi lekcje o stalinowskim terrorze, nie jest zainteresowana nazwiskami donosicieli. Notabene w dokumentach łagrowych i śledczych zostały one zamazane: „Komu one zresztą teraz potrzebne? Po co wiedzieć?” (JiM 333). Anna Griszina, przewodnicząca Polskiej Sekcji „Memoriału” w Moskwie, wyjaśnia Piotrowi Mitznerowi specyfikę rosyjskich realiów i związany z tym niekonwencjonalny stosunek tubylców do przeszłości. Otóż Andriej Sacharow na pytanie, czy na pomniku poświęconym ofiarom represji należy umieścić również nazwiska zamęczonych i rozstrzelanych katów, odpowiedział, że to powinien być pomnik wszystkich ofiar, a każdy z odwiedzających ma prawo uczcić, kogo zechce:

Przytoczyłam słowa Sacharowa, bo jeśli on w swoim głębokim humanizmie i dobroci uważał, że po śmierci nie należy odrzucać nawet katów, którzy stali się ofiarami, to tym bardziej nie należy dzielić ofiar wedle ich poglądów politycznych i zajmować się historią jednych, a wykreślać z historii innych (Mtz 37).

Autor Dzienników kołymskich w pełni podziela opinię Tomasza Kiznego, który pisał o „rosyjskiej łatwości rozgrzeszania” (HB 51). „Złego nie wspominam. Już je zapomniałam" (JiM 313) - mówi jedna z bohaterek Krasnojarska zero. Refleksje te stanowią trafną glosę do rosyjskiego dylematu: gdzie sprawca, gdzie skrzywdzony. To niezwykle drażliwa kwestia, która utrudniła rozliczenie z przeszłością i skłaniała raczej do selektywnego traktowania historii czy po prostu do niepamięci. Warto w tym miejscu przytoczyć znamienne słowa autora Archipelagu Gulag:

Gdybyż to było takie proste! - że są gdzieś te czarne charaktery, w czarnych zamiarach wykonujące swoją czarną robotę, i że trzeba tylko umieć je rozpoznać i zniszczyć. Ale linia podziału między dobrem a złem przecina serce każdego człowieka. A kto gotów jest odciąć kawałek własnego serca. [...] toż to tylko przypadek, że katami zostaliśmy nie my, tylko oni ${ }^{70}$.

Moskwa 2016, s. 19. Cyt. za: A. Kotkiewicz, ,Jedno imię, jedno życie, jeden znak”. Przywracanie pamięci o Wielkim Terrorze (1937-1938), „Przegląd Rusycystyczny” 2018, nr 3: Rosyjskie traumy - świadectwa kulturowe, red. B. Pawletko, s. 42 (przypis 20). Recenzja książki Etkinda autorstwa Bożeny Żejmo ukazała się w „Przeglądzie Rusycystycznym” 2016, nr 3, s. 145-149.

${ }^{70}$ A. Sołżenicyn, op.cit., s. 169. 
Polscy przybysze w Rosji mają do czynienia z zaskakującymi dla nich sytuacjami, które postrzegają jako paradoksy. Oto na Sołowkach w bani, miejscu na wskroś rosyjskim i na wskroś symbolicznym - o czym malowniczo opowiada autor Wilczego notesu - krzyżują się losy ludzi wspólnie korzystających z tego „demokratycznego" przybytku. Są wśród nich byli więźniowie i ich nadzorcy. Gdy Ryszard Kapuściński przechadzał się po ulicach Magadanu, odczuwał potrzebę zadawania doświadczonym starszym ludziom fundamentalnego pytania o to, kim w owym czasie byli - katem czy ofiarą, a może jednym i drugim:

W tym też była cecha stalinizmu - że w wielu wypadkach nie sposób oddzielić tych dwóch ról. Najpierw ktoś bił jako oficer śledczy, potem siedział i był bity [...]. Był to świat zamkniętego kręgu, z którego istniało tylko jedno wyjście śmierć. Była to koszmarna gra, w której przegrali wszyscy” (Kp 219).

Autor Imperium, dostrzegając na przystanku autobusowym w Workucie dwie stare kobiety, spekuluje na temat ich niegdysiejszej egzystencji w tutejszym łagrze. Być może funkcjonowały obie wedle odmiennych praw: w relacji kat-ofiara, być może los wyznaczył im diametralnie różne zadania: strażniczki i więźniarki. Czas jest nieubłagany, a jednocześnie łaskawy i pobłażliwy. Teraz jednoczy je wiek oraz bieda, a niedługo, już ostatecznie, pogodzi je zamarznięta ziemia - konkluduje.

Fundamentalne dla Zachodu pytanie: Unde malum? - w tym wypadku w wersji: Kto winien? - nie znajduje w Rosji zadowalającej odpowiedzi. Wilk w swojej pierwszej „rosyjskiej” książce przywołuje znamienne wydarzenie, którego był świadkiem. Na Wyspach odbyła się konferencja „Rosja i Sołowki” zorganizowana przez niemiecką fundację oraz rosyjski „Memoriał”. Wśród gości znaleźli się między innymi profesor Karl Schlögel, publicystka Sonia Margolina i przedstawiciele riazańskiej „Karty”, wśród dyskutantów - studenci z Moskwy. Pracownicy miejscowego muzeum nie przyjęli zaproszenia. Polski reporter z dużą rezerwą odniósł się do tego przedsięwzięcia, którego rezultatem była atrakcyjna dla przyjezdnych, ale abstrakcyjna dla miejscowych impreza. „Kto winien? Co robić? Czy przeszłość może być lekcją dla przyszłości?" (W1 71) - brzmiało zagajenie debaty. Wilk w następujący sposób prezentuje postawę młodych moskwian wówczas, gdy niefrasobliwy nastrój przemienił się już w poważną dyskusję „młodych” ze „starymi”:

Zadęciu moralnemu członków „Memoriału”, ich kategorycznemu imperatywowi wspólnej pokuty za grzechy ojców i dziadków, młodzi Rosjanie przeciwstawiali życie na własny rachunek.

- [...] Nie wolno rozliczać ludzi za grzechy przodków, bo to prowadzi do zbiorowej odpowiedzialności, a zarazem rozmywa osobistą winę - przekonuje jeden z młodzieńców. - Historię piszą raz ci, raz tamci. Z różnych obozów, 
z przeciwstawnych pozycji. Zasługi wedle jednych, bywają błędami wedle drugich i nikt nie może dać gwarancji, że za dzisiejsze medale jutro nie będziesz siedział" (W1.1 77-78).

Autor Wołoki w kontekście sołowieckiej konferencji podejmuje temat nie po raz pierwszy pojawiający się $\mathrm{w}$ dotychczasowych rozmyślaniach nad rosyjską mentalnością, czyli problem winy i grzechu. Pisarz odwołuje się do stanowiska szczególnie wyczulonego na ,przeklęte problemy” Rosji, a mianowicie Czesława Miłosza. Istotne jest tu przeciwstawienie społeczeństwa zachodniego, opartego na zasadzie winy (moja wina), społeczeństwu rosyjskiemu, opartemu na zasadzie grzechu (grzech ma charakter uniwersalny - to nie ja jestem winien, tylko zbiorowość). Stąd właściwa Rosji eschatologia, swoisty chiliazm, który znalazł swą inkarnację między innymi w komunizmie. Młodzi Rosjanie nie zamierzają kajać się za kolektywne grzechy przodków i chcą zerwać „Z wielowiekową tradycją «społeczeństwa opartego na zasadzie grzechu»»"(Wl.1 79).

Gdy polscy autorzy wspominają o fenomenie zainicjowanego przez Andrzeja Sacharowa Stowarzyszenia „Memoriał”, które - jako organizacja „sumienia społeczeństwa, sumienia narodu" "71 - zajmuje się dokumentacją zbrodni komunizmu, zazwyczaj oceniają to przedsięwzięcie $\mathrm{z}$ aplauzem (może najbardziej powściągliwy był - nie tylko zresztą w tej kwestii Mariusz Wilk). Z aprobatą i uszanowaniem o „pięknej twarzy Rosji” pisał Wacław Radziwinowicz ${ }^{72}$. Twarz ta doprawdy stanowi przeciwwagę dla groźnego i agresywnego oblicza wielkiego państwa. „Memoriał” „[t]o jest jakaś przedziwna oaza. Ludzie tam mają nawet inne twarze. Tyle że ta oaza wysycha"73 - wypowiada się z entuzjazmem i zarazem troską często goszczący w Rosji Tadeusz Klimowicz. „Memoriałowi”, a w zasadzie ludziom, którzy są z nim związani w Rosji (i w republikach byłego ZSSR), poświęcił swą książkę wspominany już Piotr Mitzner. Umieścił w niej obszerne wypowiedzi memoriałowców - świadectwo licznych, konstruktywnych z nimi spotkań. Głosy te dowodzą, że nieobca Rosjanom jest moralna wrażliwość na przeszłość, są gotowi poważnie i uczciwie traktować zobowiązania wobec niej. Nie lekceważą „obowiązku pamiętania"74. Wiąże się z powyższym kardynalny problem winy i odkupienia czy zadośćuczynienia, a co za tym idzie - poczucia odpowiedzialności. Czas bowiem niekoniecznie goi rany.

71 Słowa A. Sacharowa cytuje Piotr Mitzner (Mtz 28).

72 W. Radziwinowicz, Crème de la Kreml. 172 opowieści z Rosji, Warszawa 2016, s. 394-395.

73 T. Klimowicz, Puenty lepiej nie znać [w:] P. Brysacz, J. Morawiecki, Ani żadnej wyspy..., s. 272.

${ }^{74}$ Zob. K. Kaniowska, Etyka [w:] Modi memorandi..., s. 116-122. 
Kwestia zbiorowej odpowiedzialności najczęściej sprowadza się do problemu rozliczenia się z przeszłością; do odpowiedzialności historycznej. Dominującymi wątkami takich dyskusji są sprawy zależności między stanem świadomości historycznej a poczuciem moralnej odpowiedzialności za przeszłe zdarzenia oraz uwrażliwienie na wolną od przekłamań i uprzedzeń interpretację przeszłości (najczęściej własnej, choć nie wyłącznie $)^{75}$.

Andriej Blinuszow, jeden z rozmówców Mitznera - najpierw żołnierz i pracownik kontrwywiadu, później opozycjonista - to wnuk pułkownika NKWD. Jego dziadek nigdy nie mówił o swojej przeszłości, a chłopcu stawiany był za wzór. Obciążony rodzinnie i doświadczony życiowo Rosjanin broni się przed moralnym wygodnictwem, dostrzega problem ,winy zbiorowej" ${ }^{\text {"76 }}$, chce zatem odkupić grzechy - własne i przodków, a jednocześnie jako historyk ,rozliczyć się z historią" (Mtz 51). W tym aspekcie szczególnie znamienne wydają się słowa Lwa Kopielewa, pisarza, dysydenta politycznego w ZSRR, wypowiedziane w trakcie Tygodnia Sumienia w Warszawie (1992):

Piękne jest to spotkanie ludzi przejętych troską o prawdę o swojej przeszłości, o zbrodniach popełnionych przez naszych rodziców, starszych braci, przez nas samych. Winę ponoszą nie tylko ci spośród nas, którzy aresztowali i wsadzali do więzień, ale każdy z nas.

Kiedy człowiek traci pamięć, jest to ciężka choroba duszy i psychiki. Kiedy naród traci pamięć, jest to największe nieszczęście, to zagrożenie dla przyszłości (Mtz 60).

Powrót do przeszłości i moralny rozrachunek należy według memoriałowców uznać za rzecz konieczną, lecz warto jednocześnie zachować ostrożność w ocenie, tym bardziej że - jak wiadomo - wina ,w sensie moralnym nie jest tożsama $\mathrm{z}$ odpowiedzialnością prawną, choć w pewnych sytuacjach obszary ich definicji na siebie zachodzą"77. „Potrzebna nam jest Norymberga, ale musi być to proces w majestacie prawa" (Mtz 41) - mówi Susanna Pieczuro z moskiewskiego „Memoriału”. Uważa jednocześnie, że klątwa przeszłości w żadnym razie nie powinna spadać na dzieci i wnuki sprawców.

Karl Schlögel zwraca uwagę, że do końca trwania ZSRR nie wzniesiono pomników, które upubliczniłyby zbiorową traumę lat stalinizmu. Ofiary Stalina umarły po raz drugi - również w oczach Zachodu - ginąc w cieniu zbrodni nazistów i znikając z pamięci w obliczu ogromu ofiar Wielkiej Wojny Ojczyźnianej ${ }^{78}$. Zarzewiem działalności „Memoriału” było wystąpienie gru-

\footnotetext{
75 Ibidem, s. 120.

${ }^{76}$ K. Wigura, Wina [w:] Modi memorandi..., s. 517.

77 Ibidem, s. 516.

${ }^{78}$ Zob. K. Schlögel, Terror..., s. 11-12.
} 
py osób z inicjatywą postawienia monumentu poświęconego ofiarom represji komunistycznych między innymi na terenie stalinowskich łagrów. To miała być manifestacja przeciw-pamięci ${ }^{79}$, której celem było unaocznienie społeczeństwu katastrofy historycznej, jaka dotknęła w nieodległej przeszłości ich państwo. „Działo się to w kraju, w którym do niedawna w każdym mieście stało po kilka pomników Lenina, a miliony ofiar terroru leżą w bezimiennych mogiłach” (Mtz 29). Stopniowo niektóre projekty „strażników pamięci” wprowadzane były w życie. Jednak społeczeństwo częściej okazywało sceptycyzm i powściągliwość niż entuzjazm. Jeden z bohaterów Dzienników kołymskich opowiada:

W zeszłym roku stawialiśmy memoriał ku czci ofiar wielkiej wojny, więc pomyślałem, że będzie to też pomnik ofiar stalinowskich represji, ale większość mieszkańców się nie zgodziła. Zwołali referendum. Najbardziej, o dziwo, protestowały kobiety (HB 94).

Posługujący się najczęściej już to gniewną retoryką, już to arbitralnym osądem ${ }^{80}$ Wojciech Grzelak ze sceptycyzmem odnosi się do oficjalnych inicjatyw, które dotyczą uczczenia pamięci ofiar terroru komunistycznego (a właściwie - stalinowskiego, bo tylko tego okresu dotyczą intencje władzy). Jakkolwiek wspomina, że 30 października obchodzony jest w Rosji na mocy ustawy Dzień Pamięci Ofiar Represji Politycznych, lecz stwierdza jednocześnie, że nie jest to święto przez władze ,zbyt szumnie nagłaśniane”: „Począwszy od powstania Rosji jelcynowskiej, ofiary represji wspominane są wprawdzie otwarcie, ale dość skromnie, można powiedzieć: nieco wstydliwie"81 (Grz 177). Autor Gry z Rosja powątpiewa w szczerość słów prezydenta Dymitra Miedwiediewa wypowiedzianych w 2009 roku - ,Jestem przekonany, że pamięć o narodowych tragediach jest tak samo święta, jak pamięć o zwycięstwach" (Grz 178) - uważając, że obliczone one zostały przede wszystkim na efekt polityczny. Tym bardziej że Władimir Putin nie potępił jednoznacznie i definitywnie komunistycznych zbrodni. Mimo wszystko tego rodzaju powroty do przeszłości i bezprecedensowe enuncjacje rządowe czy nawet odezwy do narodu, z całą pewnością budzą konsternację, co więcej - niepokój części społeczeństwa, bo mimo wszystko unaoczniają, ,że rządzący bywają nie tyl-

79 „Często przeciw-pamięć koncentrowała się na znajdowaniu luk i białych plam w oficjalnej narracji o historii, a nawet we własnej biografii”. K. Bojarska, M. Solarska, Przeciw-pamięć [w:] Modi memorandi..., s. 401. Autorki odwołują się tu do ustaleń Svetlany Boym (The Future of Nostalgia, New York 2002).

${ }^{80}$ Warto wtrącić, że możliwość głębszego spojrzenia na problem daje polifonia głosów jednostkowych bohaterów, a nie dyskurs oparty na rozliczeniach i wyrzutach.

${ }^{81}$ Maria Stiepanowa opowiada o wielkiej powadze uroczystości przy pomniku zwanym Kamieniem Sołowieckim, który znajduje się na placu Łubiańskim w Moskwie. Eadem, Pamięci pamięci, przeł. A. Sowińska, Warszawa 2020, s. 431-432. 
ko omylni, ale nawet popełniają zbrodnie" (Grz 178). Spontaniczne społeczne inicjatywy, na przykład akcja „Ludzie przeciwko Stalinowi” (Grz 183), o której pisze Grzelak, pokazują żywą u części społeczeństwa potrzebę przywracania pamięci, przeciwdziałania zapomnieniu. Jednak w wielu polskich dyskursach przeważa przekonanie, że w Rosji wciąż nie ma gotowości do samokrytyki, rozliczenia się z przeszłością, a bolesne doświadczenia historyczne nie uległy przepracowaniu. Na to Rosjanie nie są jeszcze całkiem gotowi, „,[m]iędzy innymi dlatego, że rachunek taki musi relatywizować każdą władzę, uczyć nieufności do niej i zdolności do oporu, słowem, odsyłać do rozbudzonej, moralnej, jednostkowej i nieredukowalnej podmiotowości. Ta zaś jest ciężarem i krzyżem" (JiM 186) - piszą autorzy Krasnojarska zero, którym trudno byłoby zarzucić stereotypowe postrzeganie spraw rosyjskich. Niemniej jednak tworzy się w Rosji skarbnica utworów autorstwa młodszego pokolenia, w tym tekstów postmemorialnych, jakże ważnych w kraju, gdziejak pisze Maria Stiepanowa - „wir przemocy kręcił się bez ustanku - tworząc swoistą traumatyczną amfiladę, którą społeczeństwo przechadza się od jednej biedy do drugiej, od wojny do rewolucji, głodu, masowych zabójstw, nowej wojny i nowych represji $[\ldots] " 82$.

\section{Bibliografia}

\section{Bibliografia podmiotowa}

Grzelak W., Gra z Rosja do jednej bramki, rysunki S. Jołkin, Warszawa 2013.

Hugo-Bader J., Dzienniki kolymskie, Wołowiec 2011.

Jastrzębski B., Morawiecki J., Krasnojarsk zero, Warszawa 2012.

Kapuściński R., Imperium, Warszawa 1993.

Matecki J., Co wy, ..., wiecie o Rosji, Warszawa 2015.

Milczarek M., Donikąd. Podróże na skraj Rosji, Wołowiec 2019.

${ }^{82}$ Ibidem, s. 109. Do literackich prób zmierzenia się z historyczną traumą zaliczyć należy powieści Prilepina i Bykowa. Zob. P. Fast, Trauma - ekspiacja-postpamięć (na marginesie powieści ,Uniewinnienie” Dmitrija Bykowa i „Klasztor” Zachara Prilepina) [w:] idem, Uroki rosyjskiego. Szkice o ksiażkach i pisarzach, Katowice 2018, s. 192-199. Warto przywołać również opartą na rodzinnej historii Granicę zapomnienia Siergieja Lebiediewa (edycja polska w przekładzie G. Szymczaka, Warszawa 2018). Z kolei Jelena Czyżowa w powieści Miasto napisane z pamięci mierzy się z postpamięcią na temat blokady Leningradu. Zob. E. Komisaruk, Blokada Leningradu i postpamięć w powieści Jeleny Czyżowej „, Gorod, napisanyj po pamiati”, „Przegląd Rusycystyczny” 2020, nr 3, s. 130-141. Beata Pawletko pisze, że w Rosji z powodu niewypracowania odrębnych narzędzi badawczych służących zgłębianiu problematyki traumy, postraumy (również pamięci i postpamięci) korzysta się z zachodniego instrumentarium studiów nad traumą oraz odwołuje do najlepiej dotąd zgłębionych doświadczeń Holokaustu. Zob. eadem, Stowo wstępne, „Przegląd Rusycystyczny” 2018, nr 3, s. 7-11. 
Mitzner P., Memoriat. Droga do Rosji, Kraków-Warszawa 2015.

Wilk M., Wilczy notes, Gdańsk 1998.

Wilk M., Wołoka, Kraków 2005.

\section{Bibliografia przedmiotowa}

Applebaum A., Gułag, przeł. J. Urbański, Warszawa 2005.

Augé M., Formy zapomnienia, przeł. A. Turczyn, wstęp J. Mikułowski-Pomorski, Kraków 2009.

Baczyński K.K., Ten czas [w:] idem, Utwory wybrane, wybór i posłowie K. Wyka, Kraków-Wrocław 1986, s. 35.

Bereś S., Wilcza tropa. Rozmowa z Mariuszem Wilkiem [w:] idem, Historia literatury polskiej w rozmowach. XX i XXI wiek, Warszawa 2003, s. 322-343.

Bogumił Z., Pamięć GUŁagu, Kraków 2012.

Broniewski W., Ostatnia wojna [w:] idem, Poezje 1923-1961, wyb. i wstęp W. Woroszylski, Warszawa 1995, s. 52-58.

Czermińska M., Miejsca autobiograficzne. Propozycja w ramach geopoetyki, „Teksty Drugie" 2011, nr 5, s. 183-200.

Czermińska M., Tożsamość kształtowana w pamięci miejsca [w:] Kulturowa historia literatury, red. A. Łebkowska, W. Bolecki, Warszawa 2015, s. 145-160.

Darska B., Pamięć codzienności, codzienność pamiętania. Szkice o reportażu polskim XXI wieku, Gdańsk 2014.

Domańska E., Historie niekonwencjonalne. Refleksja o przeszłości w nowej humanistyce, Poznań 2006.

Esposito E., Soziales Vergessen. Formen und Medien des Gedächtnisses der Gesellschaft, trans. A. Corti, Frankfurt am Main 2002.

Fast P., Trauma - ekspiacja - postpamięć (na marginesie powieści „Uniewinnienie” Dmitrija Bykowa i „Klasztor” Zachara Prilepina) [w:] idem, Uroki rosyjskiego. Szkice o ksiażkach i pisarzach, Katowice 2018, s. 192-199.

Heidegger M., Bycie i czas, przeł. B. Baran, Warszawa 1994.

Herling-Grudziński G., Inny świat, Warszawa 1989.

Horolets A., Konformizm, bunt, nostalgia. Turystyka niszowa z Polski do krajów bytego ZSRR, Kraków 2013.

Jastrzębski M., Wypalanie traw przez opozycję [w:] P. Brysacz, J. Morawiecki, Ani żadnej wyspy. Rozmowy o Rosji i Ukrainie, Białystok 2016, s. 180-196.

Kącki M., Oświęcim. Czarna zima, Kraków 2020.

Kizny T., Damnatio Memoriae [w:] T. Kizny, współpr. D. Roynette, Wielki Terror 1937-1938, Warszawa 2013, s. 23-25.

Klimowicz T., Puenty lepiej nie znać [w:] P. Brysacz, J. Morawiecki, Ani żadnej wyspy. Rozmowy o Rosji i Ukrainie, Białystok 2016, s. 262-280.

Kolbuszewski J., Cmentarze, Wrocław 1996.

Komendant T., Sołowki - Wisła, „Twórczość” 1999, nr 3, s. 97-102.

Komisaruk E., Blokada Leningradu i postpamięć w powieści Jeleny Czyżowej „, Gorod, napisanyj po pamiati”, „Przegląd Rusycystyczny” 2020, nr 3, s. 130-141.

Konończuk E., Geograficzno-historyczny aspekt procesu literackiego [w:] Kulturowa historia literatury, red. A. Łebkowska, W. Bolecki, Warszawa 2015, s. 181-194. 
Kotkiewicz A., ,Jedno imie, jedno życie, jeden znak”. Przywracanie pamięci o Wielkim Terrorze (1937-1938), „Przegląd Rusycystyczny” 2018, nr 3: Rosyjskie traumy - świadectwa kulturowe, red. B. Pawletko, s. 36-47.

Kula M., Ostatecznie trzeba umrzeć, Warszawa 2012.

Kurczab-Redlich K., Lekcje rosyjskiego [w:] P. Brysacz, J. Morawiecki, Ani żadnej wyspy. Rozmowy o Rosji i Ukrainie, Białystok 2016, s. 50-77.

Lebiediew S., Granica zapomnienia, przeł. G. Szymczak, Warszawa 2018.

Leociak J., Doświadczenia graniczne. Studia o dwudziestowiecznych formach reprezentacji, wyd. 2 popr., Warszawa 2018.

Modi memorandi. Leksykon kultury pamięci, red. M. Saryusz-Wolska, R. Traba, współpr. J. Kalicka, Warszawa 2014.

Morawiec A., Tadeusza Różewicza wycieczka do muzeum (i biblioteki), „Czytanie Literatury. Łódzkie studia literaturoznawcze" 2013, nr 2, s. 15-36.

Nancy J.-L., Corpus, przeł. M. Kwietniewska, Gdańsk 2002.

Nola A.M., di, Tryumf śmierci. Antropologia żałoby, red. M. Woźniak, przeł. J. Kornecka, M.W. Olszańska, R. Sosnowski, M. Surma-Gawłowska, M. Woźniak, Kraków 2006.

Pawletko B., Stowo wstępne, „Przegląd Rusycystyczny” 2018, nr 3: Rosyjskie traumyświadectwa kulturowe, red. B. Pawletko, s. 7-11.

Pogonowska E., Rosja - między pamięcią a zapomnieniem ( $w$ świetle polskich dyskursów), „Slavia Orientalis” 2020, nr 1, s. 15-31.

Poolman J., Droga z kości. Podróż do mrocznego serca Rosji, przeł. J. Grzegorczyk, Poznań 2012.

Prilepin Z., Klasztor, przeł. E. Rojewska-Olejarczuk, Poznań 2016.

Próchniak P., Miejsca nieistnienia (wypisy) [w:] Pamięć i afekty, red. Z. Budrewicz, R. Sendyka, R. Nycz, Warszawa 2014, s. 491-510.

Przebinda G., Smaga J., Kto jest kim w Rosji po 1917 roku. Leksykon, Kraków 2000.

Radziwinowicz W., Crème de la Kreml. 172 opowieści z Rosji, Warszawa 2016.

Ricoeur P., Pamięć - zapomnienie - historia, przeł. J. Migasiński [w:] Tożsamość w czasach zmiany. Rozmowy w Castel Gandolfo, przedm. i oprac. K. Michalski, Kraków 1995, s. 22-43.

Roginski A., Pamięć o stalinizmie, przeł. A. Sowińska [w:] T. Kizny, współpr. D. Roynette, Wielki Terror 1937-1938, Warszawa 2013, s. 15-21.

Różewicz T., Wycieczka do muzeum [w:] idem, Proza, t. 1, Kraków 1990, s. 180-190.

Schlögel K., W przestrzeni czas czytamy. O historii cywilizacji i geopolityce, przeł.

I. Drozdowska, Ł. Musiał, posłowie H. Orłowski, Poznań 2009.

Sendyka R., Miejsca, które strasza (afekty i nie-miejsca pamięci) [w:] Pamięć i afekty, red. Z. Budrewicz, R. Sendyka, R. Nycz, Warszawa 2014, s. 285-307.

Sendyka R., Pryzma - zrozumieć nie-miejsca pamięci (non-lieux de memoire), „Teksty Drugie" 2013, nr 1-2, s. 323-344.

Sołżenicyn A., Archipelag GUŁag 1918-1956. Próba dochodzenia literackiego, cz. I-II, przeł. J. Pomianowski (M. Kaniowski), Warszawa 2000.

Sontag S., Widok cudzego cierpienia, przeł. S. Magala, Kraków 2010.

Stiepanowa M., Pamięci pamięci, przeł. A. Sowińska, Warszawa 2020.

Szałamow W., Opowiadania kołymskie, przeł. J. Baczyński, Poznań 2017, wyd. 3 popr. (dodruk). 
Szałamow W., U strzemienia, przeł. A. Pomorski [w:] idem, Procurator Judei i inne utwory, wybór L. Budrecki, Warszawa 1991, s. 82-93.

Tanaś S., Tanatoturystyka. Od przestrzeni śmierci do przestrzeni turystycznej, Łódź 2013.

Thomas L.-V., Trup. Od biologii do antropologii, przeł. K. Kocjan, Łódź 1991.

Werth N., Sołówki, laboratorium Gułagu, przedmowa [w:] S. Malsagow, N. Kisielow-Gromow, Początki Gułagu. Opowieści z Wysp Sołowieckich, przeł. M. Masny, Poznań 2019, s. 5-32.

Żejmo B., [recenzja: Aleksandr Etkind, Kriwoje gorie. Pamiat' o niepogriebiennych, awtor. pier. s ang. Wł. Makarowa, Nowoje litieraturnoje obozrienije, Moskwa 2016, s. 311], „Przegląd Rusycystyczny” 2016, nr 3, s. 145-149. 